\title{
Size-segregated urban particulate matter: mass closure, chemical composition, and primary and secondary matter content
}

\author{
Wioletta Rogula-Kozłowska ${ }^{1}$
}

Received: 3 April 2015 / Accepted: 1 July 2015 / Published online: 15 July 2015

(C) The Author(s) 2015. This article is published with open access at Springerlink.com

\begin{abstract}
Forty-nine components of ambient particulate matter $(\mathrm{PM})$ in size-fractionated $\mathrm{PM}$ were investigated at an urban background site in Katowice (Silesian Agglomeration in Southern Poland) in the non-heating season of 2012. PM was analyzed for two groups of carbon compounds (organic (OC) and elemental (EC) carbon, Lab OC-EC Aerosol Analyzer), five major water-soluble ions $\left(\mathrm{NH}_{4}^{+}, \mathrm{Cl}^{-}, \mathrm{SO}_{4}{ }^{2-}, \mathrm{NO}_{3}{ }^{-}\right.$, and $\mathrm{Na}^{+}$ contents in PM water extracts, ion chromatography), 26 elements (X-ray fluorescence spectrometry), and 16 polycyclic aromatic hydrocarbons (PAHs, gas chromatography). The distributions of the masses of these components among 13 basic PM fractions were determined, and chemical mass closure was checked for each of these fractions separately. The particles having their aerodynamic diameters in the interval $0.03-0.26 \mu \mathrm{m}$, the fraction $\mathrm{PM}_{0.03-0.26}$, contributed about $13 \%$ to the total PM mass. This PM fraction consisted of primary particles predominantly composed of various inorganic compounds, primary organic compounds, and, in lesser amounts, of elemental carbon, secondary ions, and secondary organic compounds. The second particle fraction, $\mathrm{PM}_{0.26-1.6}$, consisted mainly of secondary matter, and its mass contribution to the total PM mass was about $59 \%$. The third fraction, $\mathrm{PM}_{1.6-40}$, was a fraction of coarse particles composed of mineral/soil and organic
\end{abstract}

Wioletta Rogula-Kozłowska wioletta@ipis.zabrze.pl

1 Institute of Environmental Engineering, Polish Academy of Sciences, 34 M. Skłodowska-Curie St, 41-819 Zabrze, Poland matter and elemental carbon. It contributed to the PM mass about $28 \%$. For each of $\mathrm{PM}_{0.03-0.26}, \mathrm{PM}_{0.26-1.6}$, and $\mathrm{PM}_{1.6-40}$, the health hazard from its $16 \mathrm{PAH}$ contents was determined by computing toxicity factors. $\mathrm{PM}_{0.26-1.6}$ posed the greatest health hazard from the mixture of the 16 PAHs that it contained, $\mathrm{PM}_{1.6-40}$ was the next, and the hazard from the $\mathrm{PM}_{0.03-0.26}$-bound 16 PAHs was the smallest. The molecular diagnostic ratios computed for these three fractions were specific for coal and wood combustion; some indicated the road traffic effects.

Keywords Ambient aerosol $\cdot$ Ultrafine particles $\cdot$ Mass size distribution $\cdot$ Health hazard $\cdot$ PAHs

\section{Introduction}

Among all the air pollutants, airborne particulate matter (PM) affects the environment most extensively. PM impacts negatively on climate and human health (Englert 2004; Pope and Dockery 2006; Paasonen et al. 2013; Atkinson et al. 2015).

The PM impact on humans depends on the PM mass and number size distributions. Very small particles of PM (aerodynamic diameters up to $1 \mu \mathrm{m}$ ) are toxic, cytotoxic, and mutagenic; the PM ultrafine fraction (up to $0.1 \mu \mathrm{m}$ ) has the highest oxidative and mutagenic potential (e.g., Massolo et al. 2002; Daher et al. 2014). However, the particle size alone is not decisive in the PM toxicity. Ultrafine PM containing $\mathrm{CuO}$ is more harmful to human body cells than micrometric PM, but coarse PM containing $\mathrm{TiO}_{2}$ causes genetic damages more often than the finer PM (Karlsson et al. 2009). In fact, several PM properties mutually tangle to produce the synergistic PM toxic potential, and the size distributions and chemical composition seem to be most important. 
The chemical composition of PM directly affects the PM volatility, density, reactivity, toxicity, and so on. It accounts for time and space variations in the PM concentrations; it must be taken into account when the PM emissions are to be reduced. Providing basic information on the PM origin, the PM chemistry allows for establishing the source-receptor links.

The problems of chemical composition and identification of the sources of PM and of its particular size fractions have been studied intensely over the last years (e.g., Viana et al. 2008; Putaud et al. 2010; Spindler et al. 2010; Belis et al. 2013; Daher et al. 2014; Kong et al. 2014; Huang et al. 2014; Pokorná et al. 2015). However, neither the chemical composition nor the sources of the finest particles, those with aerodynamic diameters up to $1 \mu \mathrm{m}\left(\mathrm{PM}_{1}\right)$, are recognized well (Calvo et al. 2013). We know the least about the particles with aerodynamic diameters not greater than $0.1 \mu \mathrm{m}\left(\mathrm{PM}_{0.1}\right)$ (Sanderson et al. 2014).

The concentrations and chemical composition of PM are very site-dependent; they depend on the local emission sources and the conditions enabling chemical transformations of precursory gaseous compounds. Therefore, the monitoring of the PM concentrations and chemical composition within any area should rely on as dense a network of sampling points as possible. In Central and Eastern Europe, the chemical composition of PM, especially of fine $\mathrm{PM}\left(\mathrm{PM}_{1}, \mathrm{PM}_{2.5}\right)$, is not properly monitored because the adequate sampling points are not numerous (Viana et al. 2008; Putaud et al. 2010; Belis et al. 2013; Calvo et al. 2013; Sanderson et al. 2014).

The present work is a study of 49 PM chemical components in size-fractionated PM at an urban background site in Katowice (Southern Poland). Two groups of carbon compounds, major water-soluble ions, 16 polycyclic aromatic hydrocarbons, and 26 elements (including toxic metals $\mathrm{Ni}, \mathrm{Cd}, \mathrm{Pb}, \mathrm{As}$ ) were investigated. These chemicals were determined in 13 basic PM size fractions received directly from the impactor: $\mathrm{PM}_{0.03-0.06}, \mathrm{PM}_{0.06}$ 0.108, $\mathrm{PM}_{0.108-0.17}, \mathrm{PM}_{0.17-0.26}, \mathrm{PM}_{0.26-0.4}, \mathrm{PM}_{0.4-0.65}$, $\mathrm{PM}_{0.65-1}, \mathrm{PM}_{1-1.6}, \mathrm{PM}_{1.6-2.5}, \mathrm{PM}_{2.5-4.4}, \mathrm{PM}_{4.4-6.8}$, $\mathrm{PM}_{6.8-10}$, and $\mathrm{PM}_{10-40}$ (subscript indexes are the intervals of the particle aerodynamic diameters, $\mu \mathrm{m}$ ) and, in some, their superfractions that were defined in the course of the research. Main groups of PM components (mass closure) and contribution of primary and secondary matter and of anthropogenic and natural matter were determined separately for each of the basic fractions and then for some their superfractions. This detailed analysis allowed for the source apportionment of PM emissions in the measuring point neighborhood and provided data on the chemical composition of particular PM fractions, enabling assessment of the health hazard from PM.

\section{Methods}

\section{Organization of research and research area}

The area under research was situated within a big living quarter of Katowice (Silesian Agglomeration), beyond the direct effects of industry and road traffic (Fig. 1).

The Silesian Agglomeration lies in the center of Silesia Province, occupies $1230 \mathrm{~km}^{2}$, has about 2.1 million population (1691 inhabitants per one square kilometer). It is one of the most urbanized and industrialized regions in Central Europe.

PM was sampled at an urban background sampling point (EC 2008) between the 13 March and the 3 September 2012. Eighteen 13-fold PM samples were taken during the sampling period with the use of a 13-stage DEKATI low-pressure impactor (DLPI, Dekati Ltd.; Kangasala, Finland, flow rate 30 1/ $\mathrm{min}$ ). The particular sample takings lasted from 123 to $173 \mathrm{~h}$; they covered the whole sampling period in about $70 \%$. There was no sampling in the winter (heating season), because in Silesia, in winter, the PM chemical composition is totally dominated by carbonaceous municipal emissions (mainly elemental carbon) and is entirely different from the PM composition in the rest of the year (Pastuszka et al. 2010; RogulaKozłowska and Klejnowski 2013; Rogula-Kozłowska et al. 2014).

Two kinds of substrates were used, both from Whatman (GE Healthcare Bio-Sciences Corp.; Piscataway, NJ, USA). Alternating between the sample takings, QMA quartz fiber filters, $\varnothing 25 \mathrm{~mm}$, CAT No. 1851-025 (nine samples), and nylon membrane filters, $0.2 \mu \mathrm{m}, \varnothing 25 \mathrm{~mm}$, Cat No. 7402-002 (nine samples), were used, the same substrates on all the impactor stages in one sample taking.

Two equal $\left(1.5 \mathrm{~cm}^{2}\right)$ fragments were cut out from each exposed quartz filter just before the analysis; PM on one of them was analyzed for organic carbon (OC) and elemental carbon (EC). The remaining fragments were used to make fraction samples, each by putting together all the nine fragments containing the same PM fraction. These 13 fraction samples were analyzed for the following 16 polycyclic aromatic hydrocarbons (PAHs): naphthalene $(\mathrm{Na})$, acenaphthene (Ace), acenaphthylene (Acy), anthracene (An), benzo [a] anthracene $(\mathrm{BaA})$, benzo [a]pyrene $(\mathrm{BaP})$, benzo[b] fluoranthene $(\mathrm{BbF})$, benzo[k] fluoranthene $(\mathrm{BkF})$, benzo[g, h, i] perylene (BghiP), chrysene (Ch), dibenzo[a, h] anthracene (DBA), fluoranthene $(\mathrm{Fl})$, fluorene $(\mathrm{F})$, phenanthrene $(\mathrm{Ph})$, pyrene (Py), and indeno[1,2,3-cd]pyrene (IP).

The PM on the membrane filters was analyzed for the elemental composition (Al, Si, K, Ca, Sc, Ti, V, $\mathrm{Cr}, \mathrm{Mn}, \mathrm{Fe}, \mathrm{Co}, \mathrm{Ni}, \mathrm{Cu}, \mathrm{Zn}, \mathrm{As}, \mathrm{Se}, \mathrm{Br}, \mathrm{Rb}, \mathrm{Sr}, \mathrm{Mo}$, $\mathrm{Ag}, \mathrm{Cd}, \mathrm{Sb}, \mathrm{Te}, \mathrm{Ba}$, and $\mathrm{Pb}$ ). Then, the concentrations of water-soluble ions $\left(\mathrm{Cl}^{-}, \mathrm{SO}_{4}{ }^{2-}, \mathrm{NO}_{3}{ }^{-}, \mathrm{Na}^{+}, \mathrm{NH}_{4}{ }^{+}\right)$ were determined in the PM water extracts. 


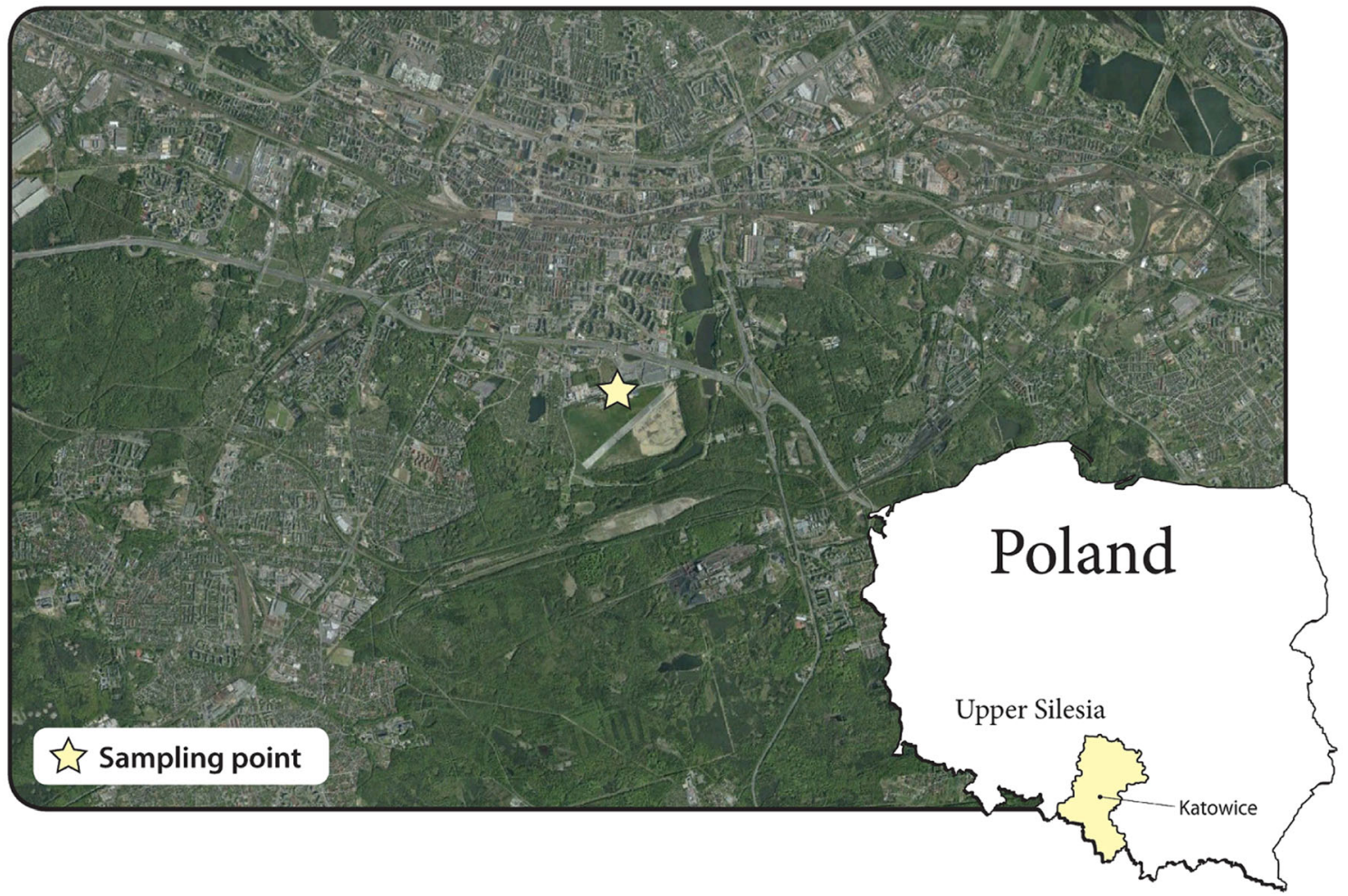

Fig. 1 The sampling point location

\section{Chemical analyses, QA/QC}

The substrates and impactors were prepared for exposure in a laminar chamber. The masses of the PM samples were determined by weighing the substrates before and after the exposure; a MYA 5.3Y.F micro balance (1- $\mu \mathrm{g}$ resolution, RADW AG; Radom, Poland) was used. Before each weighing, the substrates were conditioned for $48 \mathrm{~h}$ in the weighing room (relative air humidity $45 \pm 5 \%$, air temperature $20 \pm 2{ }^{\circ} \mathrm{C}$ ). After weighing, the exposed filters were put into petri dishes which were wrapped in light-proof aluminum foil and stored in a freezer at $-18^{\circ} \mathrm{C}$ till the analysis.

Blank samples were prepared for each of the 13 basic PM fractions. The four-step process of preparing the blanks consisted of (1) taking out 13 filters from their original package and putting them into Petri dishes; (2) 48-h conditioning of the filters in Petri dishes in the weighing room; (3) loading the Dekati impactor with the filters and installing the impactor at the measuring site for 5 days (pump off); (4) removing the filters from the impactor, putting back into Petri dishes, and 48 - $\mathrm{h}$ conditioning in the weighing room. The process was repeated for both kinds of filters at the beginning and at the end of the measuring period. The blanks were used to determine the detection limits for the analytical methods and the analyte background levels (the amount of the analyte in a blank, $\mu \mathrm{g}$, determined for each PM basic fraction separately). Neither PM component analytical background was greater than $3.5 \%$ of the component content of the PM sample. The analyte content of a PM sample was received by subtracting its background level value from its amount on the exposed filter.

The OC and EC contents of PM were determined with the use of a Lab OC-EC Aerosol Analyzer (Sunset Laboratories Inc.; Portland, OR, USA) using the EUSAAR protocol. The measurement performance was controlled by systematic calibrating of the analyzer within the range proper for the determined concentrations and by analyzing standards with certified carbon content (RM 8785 and RM 8786, NIST, Gaithersburg, MD, USA) and the blank samples.

The detection limit for total carbon (TC), computed after analyzing the 26 blanks, was $0.52 \mu \mathrm{g} \mathrm{C} / \mathrm{cm}^{2}(0.43$ and $0.09 \mu \mathrm{g}$ $\mathrm{C} / \mathrm{cm}^{2}$ for OC and EC, respectively). The standard recovery was from 98 to $122 \%$ of the certified value for OC and from 95 to $116 \%$ for EC (the certified values were taken from the IMPROVE program).

The detailed description of the extraction procedure and the parameters of the chromatographic analysis of PM for PAHs are in given in Rogula-Kozłowska et al. (2013b).

The limits of detection for the $16 \mathrm{PAHs}$, obtained from the statistical development of the blank results (26 above described quartz fiber filter blanks), were between $6.25 \mathrm{ng}$ $(\mathrm{BbF})$ and $20 \mathrm{ng}(\mathrm{Ph})$.

The method performance was verified by analyzing the NIST SRM1649b reference material and comparing the 
results with the certified concentrations of the investigated PAHs. The standard recoveries were from $92 \%(\mathrm{Ph})$ to $111 \%$ (Acy).

The elemental composition of PM was determined by means of energy-dispersive X-ray fluorescence (EDXRF). An Epsilon 5 (PANalytical B.V.; Almelo, The Netherlands), calibrated with the use of thin-layer single-element standards (Micromatter; Vancouver, Canada), was used to measure the total concentrations of the elements. To control the performance of the analytical procedure, the NIST SRM2873 samples were measured weekly (except 52 and $39 \%$ recoveries of $\mathrm{V}$ and $\mathrm{Co}$, the recoveries were between 85 and $120 \%$ of the certified values) and the X-ray tube and detector drift monitor monthly. The detection limits (from the statistical development of the blank results) were from $0.15 \mathrm{ng} / \mathrm{cm}^{2}$ (Se) to $16.8 \mathrm{ng} / \mathrm{cm}^{2}(\mathrm{Si})$.

The water extracts of PM were made by ultrasonizing the substrates containing the samples in $25 \mathrm{~cm}^{3}$ of de-ionized water for $60 \mathrm{~min}$ at the temperature $15^{\circ} \mathrm{C}$ and then shaking the extracts for about $12 \mathrm{~h}\left(18{ }^{\circ} \mathrm{C}, 60 \mathrm{r} / \mathrm{min}\right)$. The ion content of the extracts was determined using an ion chromatograph (Metrohm AG; Herisau, Switzerland). The method was validated against the CRM Fluka product nos. 89316 and 89886; the standard recoveries were from $92 \%\left(\mathrm{Na}^{+}\right)$to $109 \%\left(\mathrm{Cl}^{-}\right)$ of the certified values, and the detection limits were as follows: $10 \mathrm{ng} / \mathrm{cm}^{3}$ for $\mathrm{NH}_{4}{ }^{+}, 18 \mathrm{ng} / \mathrm{cm}^{3}$ for $\mathrm{Cl}^{-}$and $\mathrm{SO}_{4}{ }^{2-}$, and $27 \mathrm{ng} / \mathrm{cm}^{3}$ for $\mathrm{NO}_{3}{ }^{-}$and $\mathrm{Na}^{+}$.

\section{Estimation of secondary matter content of size-segregated PM}

The ambient concentrations of fraction-bound secondary organic carbon $\left(\mathrm{OC}_{\mathrm{sec}}\right)$, ammonium sulfate $\left(\left(\mathrm{NH}_{4}\right)_{2} \mathrm{SO}_{4}\right)$, and ammonium nitrate $\left(\mathrm{NH}_{4} \mathrm{NO}_{3}\right)$ were determined from the analytically determined amounts of $\mathrm{OC}, \mathrm{EC}, \mathrm{SO}_{4}{ }^{2-}$, and $\mathrm{NH}_{4}{ }^{+}$in PM.

The mass $\left[\mathrm{OC}_{\mathrm{sec}}\right]^{\mathrm{sf}}$ of the $\mathrm{OC}_{\mathrm{sec}}$ from the basic fraction $f$ in the sample $s$ is computed from the equation (Castro et al. 1999):

$\left[\mathrm{OC}_{\mathrm{sec}}\right]^{\mathrm{s} f}=[\mathrm{OC}]_{\mathrm{A}}^{\mathrm{s} f}-\left(\frac{[\mathrm{OCC}]_{\mathrm{A}}^{f}}{[\mathrm{ECC}]_{\mathrm{A}}^{f}}\right)_{\text {min }} \cdot[\mathrm{EC}]_{\mathrm{A}}^{\mathrm{s} f}$

where

$[\mathrm{OC}]_{\mathrm{A}}^{\mathrm{sf}}$ is the analytically determined mass of the $\mathrm{OC}$ from the fraction $f$ in the sample $s$,

$[\mathrm{EC}]_{\mathrm{A}}^{\mathrm{sf}}$ is the analytically determined mass of the EC from the fraction $f$ in the sample $s$,

$\left([\mathrm{OC}]_{\mathrm{A}}^{f} /[\mathrm{EC}]_{\mathrm{A}}^{\mathrm{A}}\right)_{\text {min }}$ is the smallest $[\mathrm{OC}]_{\mathrm{A}}^{\mathrm{s} f} /[\mathrm{EC}]_{\mathrm{A}}^{\mathrm{s} f}$ for all the samples $s$ of the fraction $f\left(\left([\mathrm{OC}]_{\mathrm{A}}^{f} /[\mathrm{EC}]_{\mathrm{A}}^{f}\right)_{\text {min }}\right.$ for all the PM fractions are presented in Table 1).

The masses $\left[\left(\mathrm{NH}_{4}\right)_{2} \mathrm{SO}_{4}\right]^{\mathrm{sf} f}$ and $\left[\mathrm{NH}_{4} \mathrm{NO}_{3}\right]^{\mathrm{sf} f}$ of the $\left(\mathrm{NH}_{4}\right)_{2} \mathrm{SO}_{4}$ and $\mathrm{NH}_{4} \mathrm{NO}_{3}$ in the basic fraction $f$ in the sample $s$ are computed from the following formulas (Cheng et al. 2005):

When the proportion of the concentrations of $\mathrm{SO}_{4}{ }^{2-}$ and $\mathrm{NH}_{4}{ }^{+}$(neq $/ \mathrm{m}^{3}$; Table 1$)$ is less than 1 ,

$\left[\left(\mathrm{NH}_{4}\right)_{2} \mathrm{SO}_{4}\right]^{\mathrm{s} f}=1.38\left[\mathrm{SO}_{4}{ }^{2-}\right]_{\mathrm{A}}^{\mathrm{s} f}$

$\left[\mathrm{NH}_{4} \mathrm{NO}_{3}\right]^{\mathrm{s} f}=4.44\left[\mathrm{ex}^{-\mathrm{NH}_{4}}{ }^{+}\right]^{\mathrm{s} f}$

$\left[\mathrm{ex}^{-\mathrm{NH}_{4}}{ }^{+}\right]^{\mathrm{s} f}=\left[\mathrm{NH}_{4}^{+}\right]_{\mathrm{A}}^{\mathrm{sf}}-0.27\left[\left(\mathrm{NH}_{4}\right)_{2} \mathrm{SO}_{4}\right]^{\mathrm{s} f}$

where

$\left[\mathrm{SO}_{4}{ }^{2-}\right]_{\mathrm{A}}^{\mathrm{sf}}$ is the analytically determined mass of $\mathrm{SO}_{4}{ }^{2-}$ from the fraction $f$ in the sample $s$,

$\left[\mathrm{NH}_{4}^{+}\right]_{\mathrm{A}}^{\mathrm{s} f}$ is the analytically determined mass of $\mathrm{NH}_{4}{ }^{+}$ from the fraction $f$ in the sample $s$,

[ex-NH$\left.{ }_{4}^{+}\right]^{\mathrm{sf}}$ amount (mass) of $\mathrm{NH}_{4}^{+}$from the fraction $f$ left after the reaction with $\mathrm{SO}_{4}{ }^{2-}$ (excessive $\mathrm{NH}_{4}{ }^{+}$) in the sample $s$,

When the proportion of the concentrations of $\mathrm{SO}_{4}{ }^{2-}$ and $\mathrm{NH}_{4}^{+}$(neq $/ \mathrm{m}^{3}$; Table 1$)$ is not less than 1 ,

$\left[\left(\mathrm{NH}_{4}\right)_{2} \mathrm{SO}_{4}\right]^{\mathrm{s} f}=3.67\left[\mathrm{NH}_{4}{ }^{+}\right]_{\mathrm{A}}^{\mathrm{s} f}$

$\left[\mathrm{NH}_{4} \mathrm{NO}_{3}\right]^{\mathrm{s} f}=0$

\section{Results and discussion}

\section{Concentration and mass size distribution of PM and PM components}

The minima, maxima, and averages in the measuring period of ambient concentrations for each substance determined analytically in each basic PM fraction, except for the 16 PAHs whose extreme concentrations were not measured, are presented in Table 1; together with the values of some parameters employed in computing, these values for the ambient concentrations of $\mathrm{OC}_{\mathrm{sec}},\left(\mathrm{NH}_{4}\right)_{2} \mathrm{SO}_{4}$, and $\mathrm{NH}_{4} \mathrm{NO}_{3}$ are also presented in Table 1.

In Katowice, the core PM mass was due to $\mathrm{PM}_{0.26-1.6}$ (Table 1). The measuring period average $\mathrm{PM}_{0.26-1.6}$ concentration was $14.5 \mu \mathrm{g} / \mathrm{m}^{3}$, about $60 \%$ of the $\mathrm{PM}_{10}$ concentration. The remaining $40 \%$ was divided between $\mathrm{PM}_{0.03-0.26}$ and $\mathrm{PM}_{1.6-10}$ in the proportion of 1:2. The masses of the main $\mathrm{PM}$ components were also concentrated in $\mathrm{PM}_{0.26-1.6}$. By mass, about $50 \%$ of $\mathrm{Cl}^{-}, 60 \%$ of $\mathrm{NO}_{3}^{-}, 70 \%$ of $\mathrm{OC}$ and $\mathrm{SO}_{4}{ }^{2-}$, and $80 \%$ of $\mathrm{Na}^{+}$were in $\mathrm{PM}_{0.26-1.6}$, from $11 \%\left(\mathrm{Na}^{+}\right)$ to $21 \%\left(\mathrm{Cl}^{-}\right)$in $\mathrm{PM}_{0.03-0.26}$, and from $10 \%\left(\mathrm{Na}^{+}\right)$to $40 \%$ (EC) in $\mathrm{PM}_{1.6-10}$.

The density function of the PM mass distribution with respect to particle size has its absolute (greatest local) maximum 


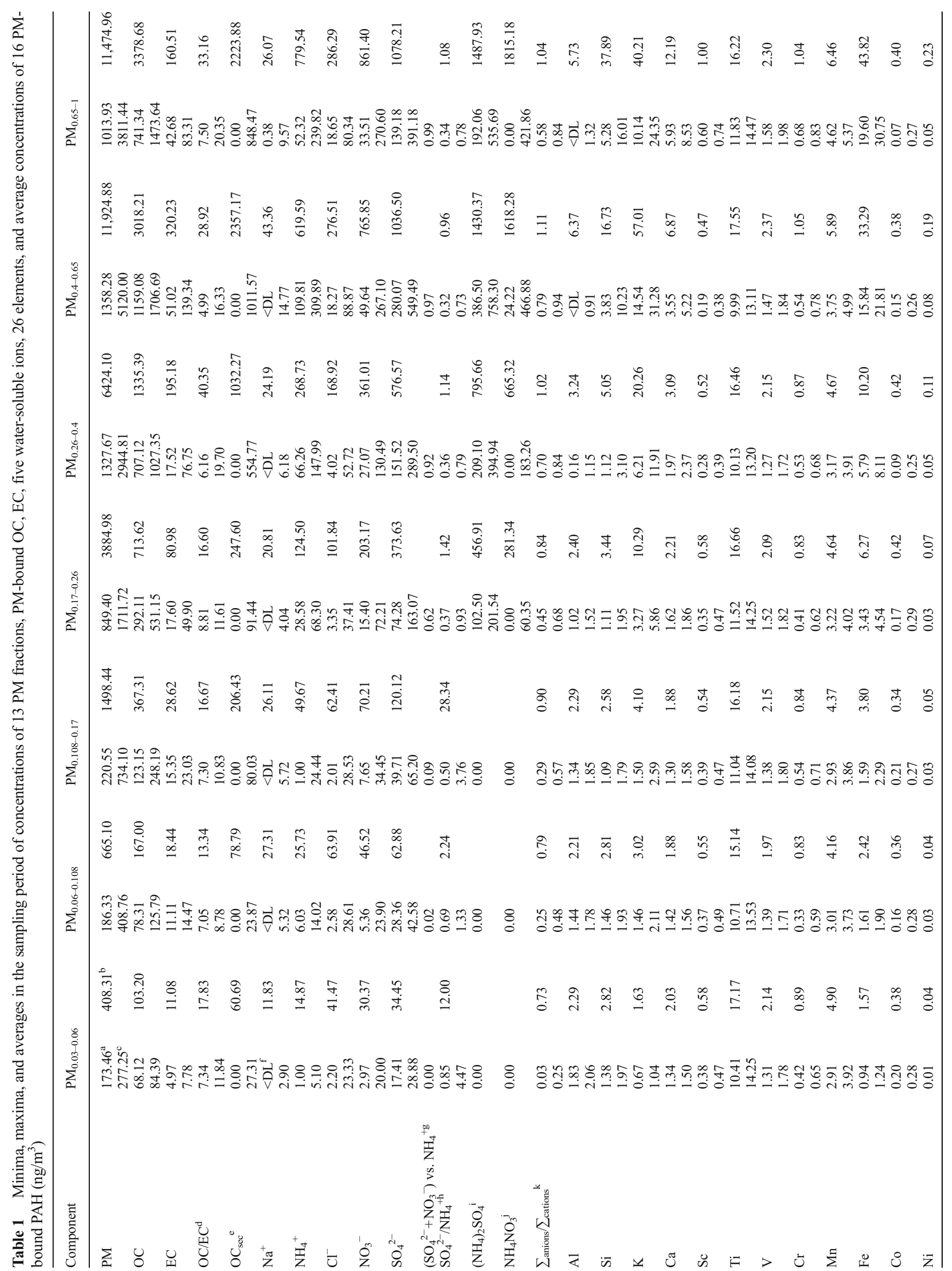




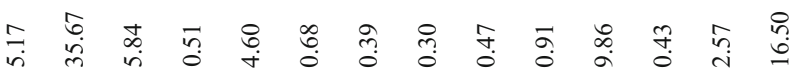

茛

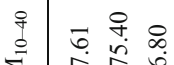

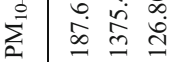

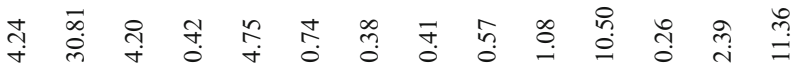

$\sum_{\substack{0 \\ 0}}^{+}$

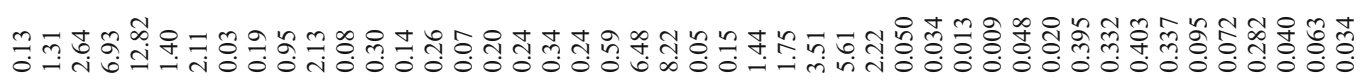

$\sum_{\substack{\infty \\ \infty}}^{\substack{\infty \\ 0}}$

다 守

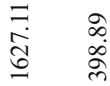

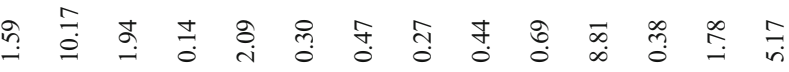

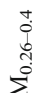

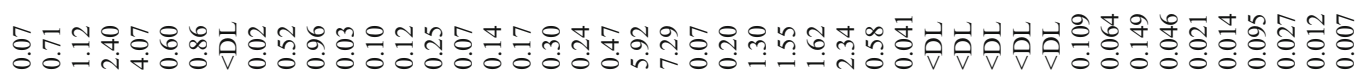

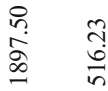

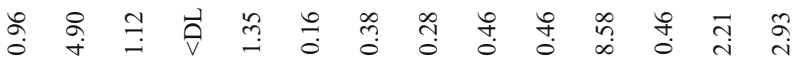

$\sum_{\substack{i \\ 0}}^{\substack{0 \\ \vdots}}$

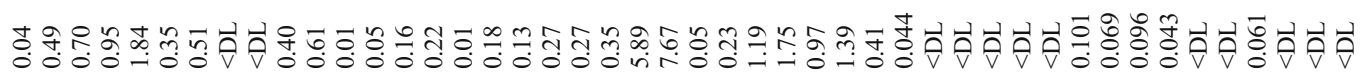

당

$\sum_{\substack{0 \\ 0}}^{5}$

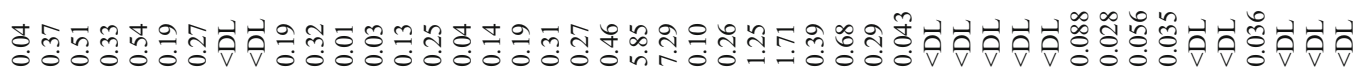

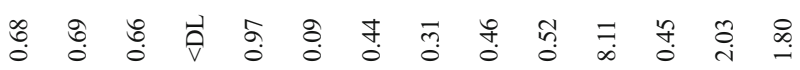

0
0
0
0
0
0
$\vdots$

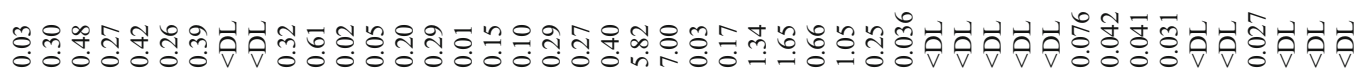

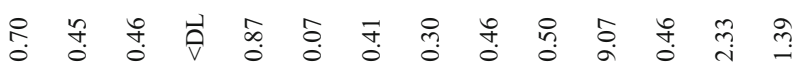

ind

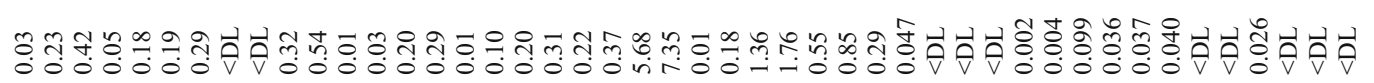

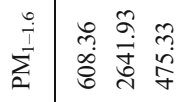

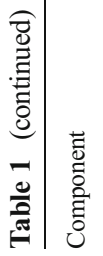

も 


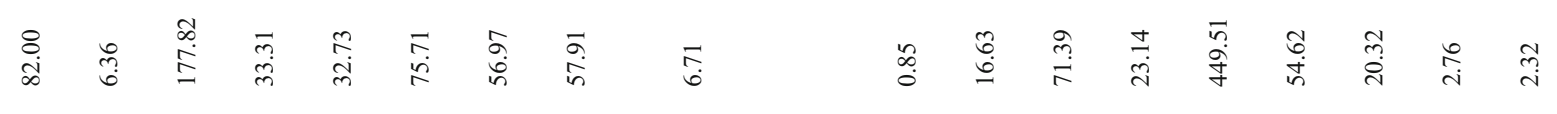

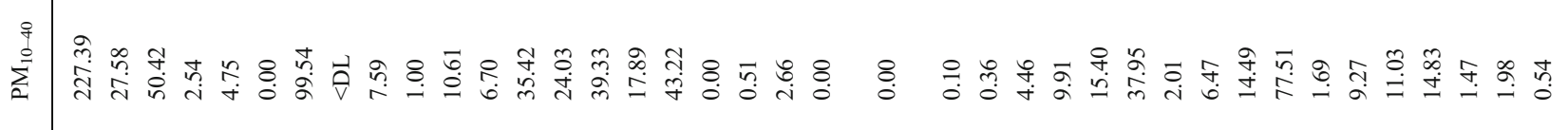

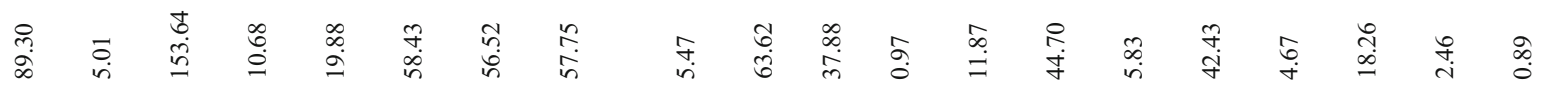

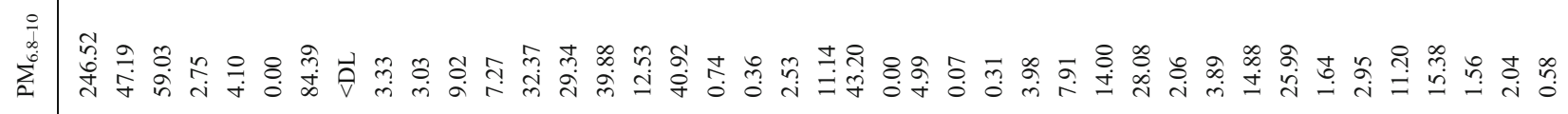
孚

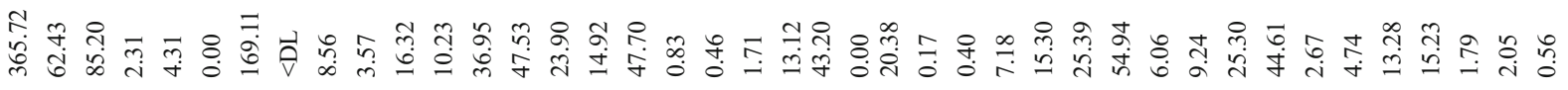

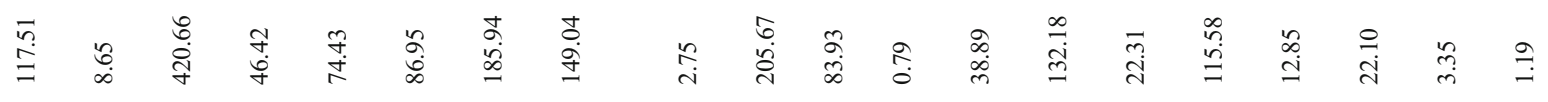

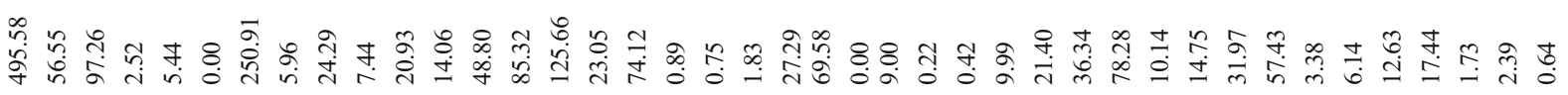

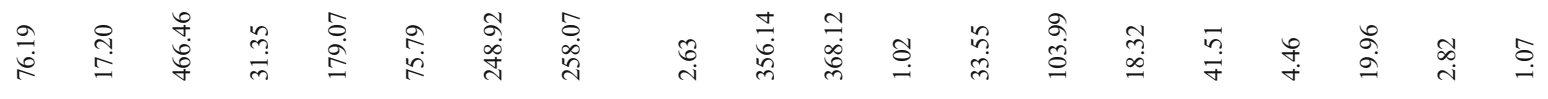

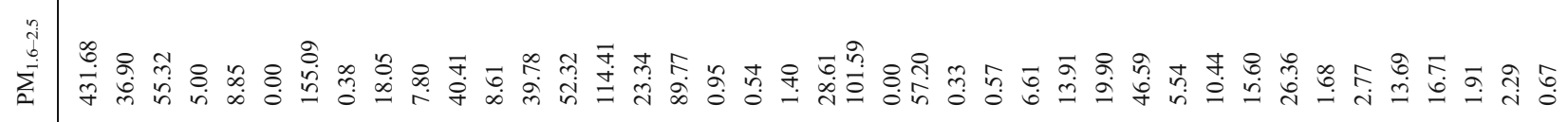

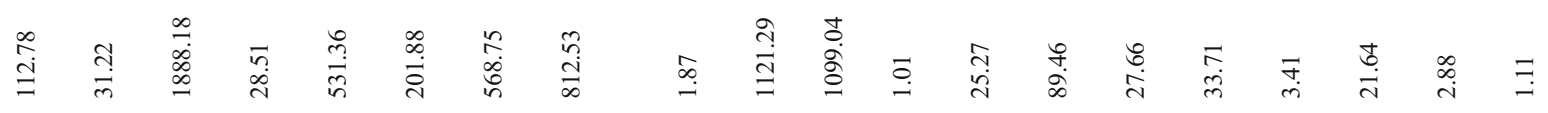

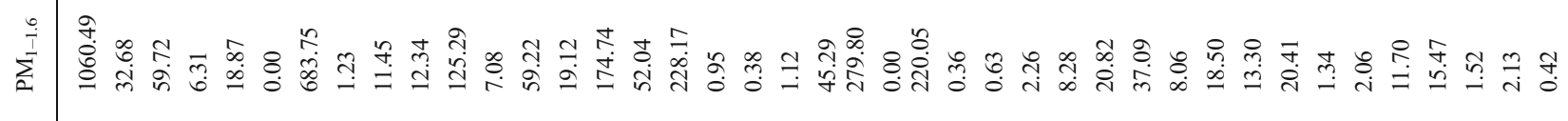

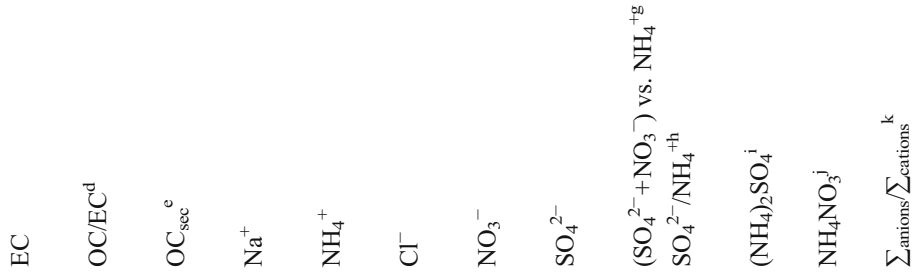




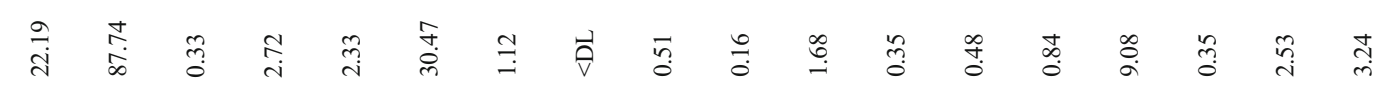

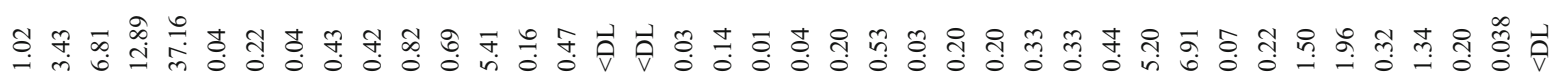

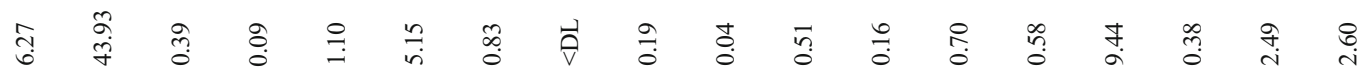

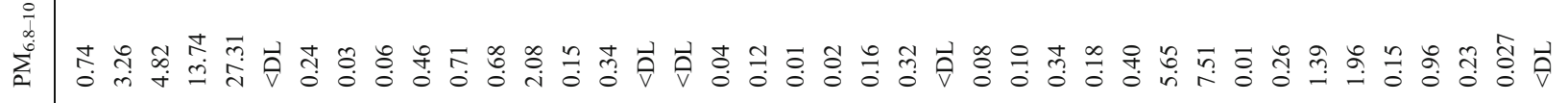

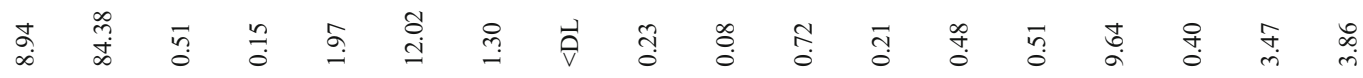

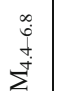

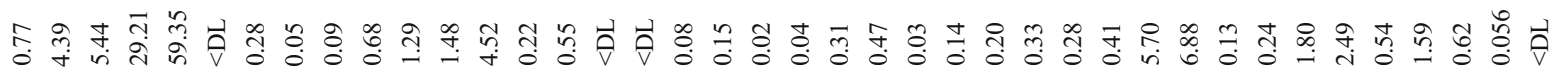

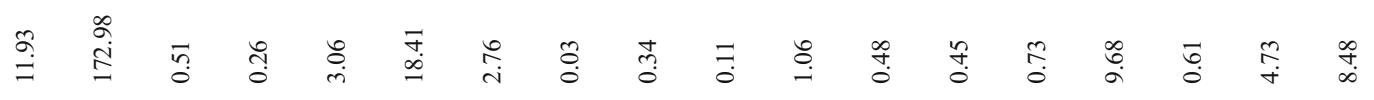

$\sum_{\substack{n \\ \vdots}}^{+}$

مू

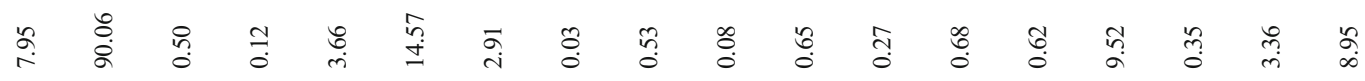

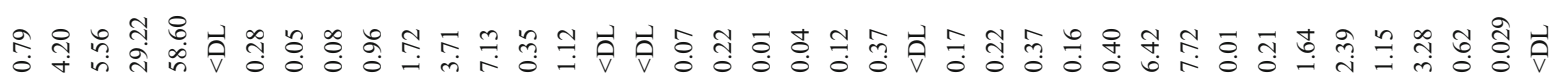

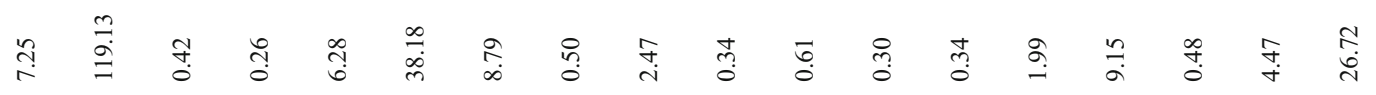

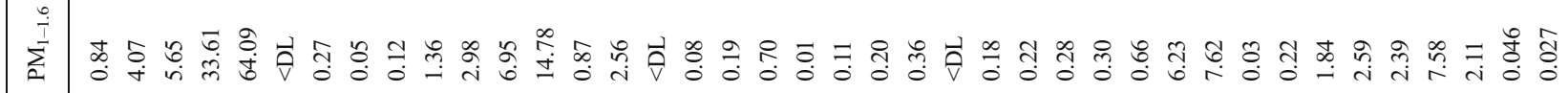

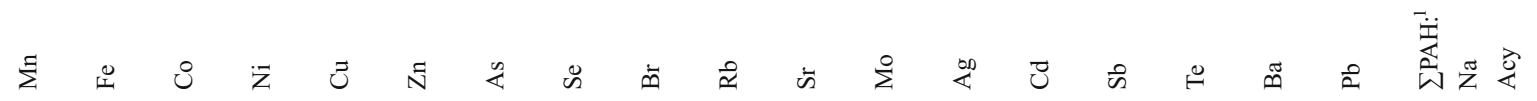




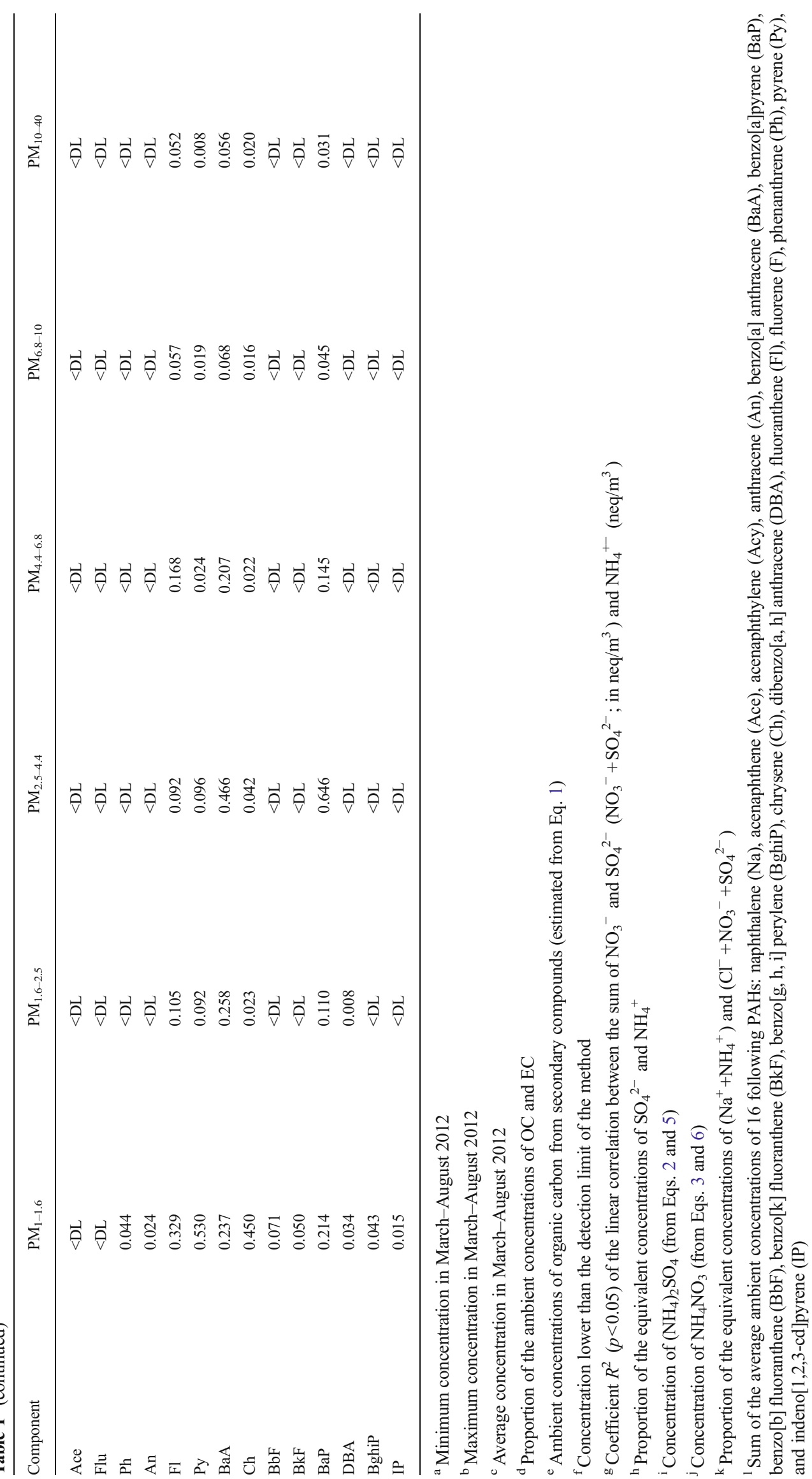


at the point (the greatest frequency mode, main mode) between 0.4 and $0.65 \mu \mathrm{m}$ (Fig. 2). The lack of a mode within the greatest diameters indicates the relatively small share of natural mineral components in PM. Nucleation was not a significant PM source during the measuring period either (Friedlander 1970, 1971; Seinfeld and Pandis 2006). Nevertheless, for both $\mathrm{PM}_{6.8-40}$ and $\mathrm{PM}_{0.108-0.4}$, the proportion of the maximum to minimum concentrations in the measuring period is high, so, the activity of natural mineral matter and nucleation as PM sources varied quite widely not affecting visibly the PM mass size distribution. Similar results were obtained for summer in Zabrze, about $15 \mathrm{~km}$ east of Katowice (Klejnowski et al. 2012).

The PM-bound $\mathrm{OC}, \mathrm{EC}, \mathrm{NH}_{4}{ }^{+}, \mathrm{SO}_{4}{ }^{2-}, \mathrm{Cl}^{-}$, and $\mathrm{NO}_{3}{ }^{-}$mass size distributions have their main modes in the interval 0.4 $1 \mu \mathrm{m}$, like the distribution of PM (Fig. 2). The distribution of EC is bimodal (the second mode for EC is in 4.4-6.8 $\mu \mathrm{m}$ ); the rest are unimodal. The $\mathrm{Na}^{+}$distribution is trimodal; its main mode is in the interval 2.5-4.4 $\mu \mathrm{m}$. The two other modes are in $0.108-0.17 \mu \mathrm{m}$ and $0.65-1 \mu \mathrm{m}$. While the presence of the mode for $\mathrm{Na}^{+}$in 2.5-4.4 $\mu \mathrm{m}$ is accounted for by the road dust or soil contamination with $\mathrm{NaCl}$ (Pant and Harrison 2013; Li et al. 2014), the mode for EC within such great diameters is not typical; it should rather be expected within very small diameters (ultrafine particles), as the traffic emissions are dominant in summer (Maricq 2007; Alves et al. 2015).

Most probably, the distance caused the traffic EC to reach the sampling point as big particles of soot; EC in coarse particles may be attributed to traffic-induced non-exhaust emissions (Amato et al. 2014). Moreover, the effect of emissions from household coal combustion, although weaker than in winter, cannot be totally excluded. Household ovens, active in the region in the whole year, release big particles of soot from incomplete hard coal combustion. These particles adsorb great amounts of light organic compounds on their surface, contributing to PM-bound OC; the mass distributions of PMbound secondary organic carbon $\left(\mathrm{OC}_{\mathrm{sec}}\right)$ and of primary organic carbon $\left(\mathrm{OC}_{\text {prim }}\right)$ have the modes in the interval of big particle diameters.

Except for $\mathrm{Na}^{+}$, PM-bound water-soluble ions have unimodal mass size distributions (Fig. 2). The ratios $\Sigma_{\text {anions }} /$ $\Sigma_{\text {cations }}$ of the total anion concentration $\left(\Sigma_{\text {anions }}, \frac{\text { neq }}{\mathrm{m}^{3}}\right)$ to the total cation concentration $\left(\Sigma_{\text {anions }}, \frac{n e q}{\mathrm{~m}^{3}}\right)$, both minimum and average, are smaller than 1 for all the basic fractions (Table 1$)$. Because $\Sigma_{\text {anions }}$ and $\Sigma_{\text {cations }}$ are highly linearly correlated $\left(R^{2}=0.98, p<0.05\right), \mathrm{SO}_{4}{ }^{2-}, \mathrm{NO}_{3}{ }^{-}$, and $\mathrm{Cl}^{-}$were most probably in compounds with $\mathrm{Na}^{+}$and $\mathrm{NH}_{4}{ }^{+}$in majority of the fractions (Seinfeld and Pandis 2006; Kong et al. 2014).
Fig. 2 Mass size distribution of $\mathrm{PM}$ and its components $(d C \mathrm{PM}$ or PM fraction-bound component concentration, $C$ average concentration of PM or PMbound component, $D p$ particle aerodynamic diameter)
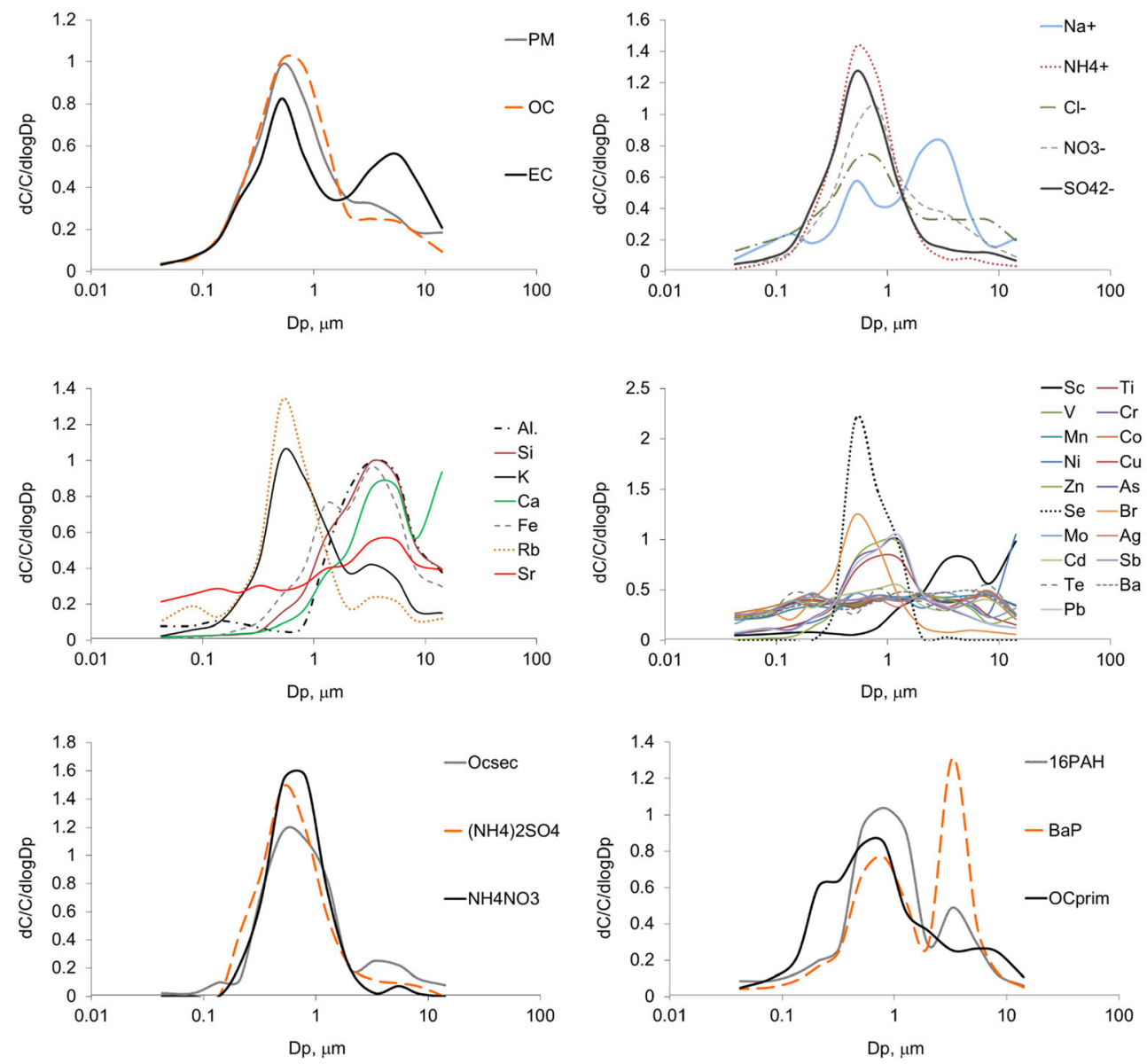
The coarse particles (to a lesser extent ultrafine particles too) contained probably $\mathrm{NaCl}$ and $\mathrm{NaNO}_{3}$ (modes of the $\mathrm{Cl}^{-}$and $\mathrm{NO}_{3}{ }^{-}$distributions were shifted toward big particle diameters relative to other ion distribution modes); $\mathrm{Na}_{2} \mathrm{SO}_{4}, \mathrm{NH}_{4} \mathrm{NO}_{3}$, $\left(\mathrm{NH}_{4}\right)_{2} \mathrm{SO}_{4}$, and $\mathrm{NH}_{4} \mathrm{Cl}$ were mainly in fine $\mathrm{PM}$ (but in coarse particles too). Obviously, in PM, the three determined watersoluble ions, $\mathrm{SO}_{4}{ }^{2-}, \mathrm{NO}_{3}{ }^{-}$, and $\mathrm{Cl}^{-}$, can also occur bound to chemicals other than water-soluble ions, different in different fractions.

The majority of the mass size distributions of PM-bound elements are bi- or tri-modal (Fig. 2). The distributions of Se, $\mathrm{Br}, \mathrm{Pb}, \mathrm{Cu}, \mathrm{Zn}$, As, and $\mathrm{K}$, the elements related to solid (including coal and biomass) and liquid fuel combustion (Chow 1995; Kumar et al. 2013; Sanderson et al. 2014; Zhang et al. 2014), have very distinctive (of high frequency) modes in the interval $0.4-0.65 \mu \mathrm{m}$. Some have the modes in the interval of smaller diameters, like those for $\mathrm{Mn}, \mathrm{Fe}, \mathrm{Co}, \mathrm{Cd}, \mathrm{Ni}, \mathrm{V}$, and Mo, the elements released probably by traffic (Geller et al. 2006; Sanderson et al. 2014) and industry (Chow 1995; Kumar et al. 2013) as oxides which aggregate to form the particle nucleation mode in the air. Majority of the element distributions have also the modes in the interval of greater diameters, proving their partially non-exhaust origin (Adachi and Tainosho 2004; Wahlin et al. 2006; Pant and Harrison 2013). The elements such as $\mathrm{Al}, \mathrm{Si}$, and $\mathrm{Ca}$, whose distributions have the modes in the interval of great diameters, came probably from soil/mineral matter resuspension.

\section{Chemical mass closure of size-resolved PM}

The analytically determined PM components can occur in PM as chemical elements, in chemical compounds with other PM components, or, not numerous, they are chemical compounds themselves. Quite naturally, they fall into five categories according to their origin and the analytical methods used to find their masses in the PM samples: organic carbon (OC) from PM-bound organic compounds; elemental carbon (EC) from incomplete combustion; secondary ions $\mathrm{SO}_{4}{ }^{2-}, \mathrm{NO}_{3}{ }^{-}$, and $\mathrm{NH}_{4}{ }^{+}$; crustal elements, and anthropogenic (trace) elements. Their masses in PM samples, being the sums of the analytically received masses of their members, account for the greater part of the PM mass (Table 1), but there is still some deficient mass, the mass of all the substances from beyond these categories, which can be lowered by taking into account the origin of the analytically determined elemental PM components and which is also significant in the chemical content of PM.

Organic carbon (OC) comes from PM-bound organic compounds that can be divided into secondary organic matter (SOM) and primary organic matter (POM). Their masses, $[\mathrm{SOM}]$ and $[\mathrm{POM}]$, in the sampled PM are computed from the mass $[\mathrm{OC}]_{\mathrm{A}}$ of the analytically determined $\mathrm{OC}$ and the mass $\left[\mathrm{OC}_{\mathrm{sec}}\right]$ of secondary organic carbon $\left(\mathrm{OC}_{\mathrm{sec}}\right.$, namely
$[\mathrm{SOM}]=1.6\left[\mathrm{OC}_{\mathrm{sec}}\right]$ and $[\mathrm{POM}]=1.2\left([\mathrm{OC}]_{\mathrm{A}^{-}}\left[\mathrm{OC}_{\mathrm{sec}}\right]\right) . \mathrm{A}$ lower conversion factor is taken for the [POM] than for the [SOM] calculation (Turpin and Lim 2001).

For all the basic sub-fractions of $\mathrm{PM}_{0.17-10}$, the masses $\left[\mathrm{NH}_{4}{ }^{+}\right]$and $\left[\mathrm{NO}_{3}{ }^{-}\right]+\left[\mathrm{SO}_{4}{ }^{2-}\right]$ are linearly correlated (Table 1); therefore, in these fractions, some amounts of $\mathrm{NH}_{4}{ }^{+}, \mathrm{NO}_{3}{ }^{-}$, and $\mathrm{SO}_{4}{ }^{2-}$ occur probably as $\left(\mathrm{NH}_{4}\right)_{2} \mathrm{SO}_{4}$ and $\mathrm{NH}_{4} \mathrm{NO}_{3}$. For these basic fractions, the secondary inorganic matter (SIM) is assumed to consist of $\left(\mathrm{NH}_{4}\right)_{2} \mathrm{SO}_{4}$ and $\mathrm{NH}_{4} \mathrm{NO}_{3}$, and $[\mathrm{SIM}]=\left[\left(\mathrm{NH}_{4}\right)_{2} \mathrm{SO}_{4}\right]+\left[\mathrm{NH}_{4} \mathrm{NO}_{3}\right]$. For the fractions $\mathrm{PM}_{0.03-0.06}, \mathrm{PM}_{0.06-0.108}, \mathrm{PM}_{0.108-0.17}$, and $\mathrm{PM}_{10-40}$, for which the masses $\left[\mathrm{NH}_{4}{ }^{+}\right]$and $\left[\mathrm{NO}_{3}{ }^{-}\right]+\left[\mathrm{SO}_{4}{ }^{2-}\right]$ are not correlated and, in which, consequently, $\mathrm{NH}_{4}{ }^{+}, \mathrm{NO}_{3}{ }^{-}$, and $\mathrm{SO}_{4}{ }^{2}$ were assumed to occur neither as $\left(\mathrm{NH}_{4}\right)_{2} \mathrm{SO}_{4}$ nor as $\mathrm{NH}_{4} \mathrm{NO}_{3}$, SIM is assumed to be empty and [SIM] $=0$.

Finally, mineral matter (MM) and anthropogenic trace matter (ATM) are built of chemical compounds of the PM-bound elements from Table 1: MM consists of the compounds of the crustal elements, and ATM consists of the compounds of the anthropogenic elements.

The groups of crustal and trace elements are defined by dividing all the determined elements into two categories using the enrichment factors (EF; Rogula-Kozłowska et al. 2014) and analyzing their mass size distributions (Fig. 2). For all the basic fractions, $\mathrm{Si}, \mathrm{Al}$, and $\mathrm{Ca}$ have low EFs, not greater than 16 (Table 2). They accumulated in coarse particles, and their mass size distributions are unimodal with the mode in the interval of the particle diameters greater than $2.5 \mu \mathrm{m}$. This and their EFs suggested their crustal origin for all the basic fractions. $\mathrm{K}, \mathrm{Fe}, \mathrm{Rb}$, and $\mathrm{Sr}$ in coarse PM have the EFs low, decreasing with growing particle diameter. Their distributions are bimodal, with one mode in the diameters greater than $2.5 \mu \mathrm{m}$, like the distributions of $\mathrm{Si}, \mathrm{Al}$, and $\mathrm{Ca}$, the second one in the diameters less than $1 \mu \mathrm{m}$. The second mode indicates the presence of an anthropogenic fine particle population (accumulation mode) containing $\mathrm{K}, \mathrm{Fe}, \mathrm{Rb}$, and Sr. Thus, $\mathrm{PM}_{1-40}$-bound $\mathrm{K}, \mathrm{Fe}, \mathrm{Rb}$, and $\mathrm{Sr}$ are crustal, and $\mathrm{PM}_{0.03-1^{-}}$ bound $\mathrm{K}, \mathrm{Fe}, \mathrm{Rb}$, and $\mathrm{Sr}$ are anthropogenic. The rest of the elements, $\mathrm{Cl}^{-}$and $\mathrm{Na}^{+}$, are anthropogenic in each of the basic fractions. They are assumed to be anthropogenic because they have high EFs and the main modes of their distributions are in the particle diameters less than $1 \mu \mathrm{m}$. The distributions of $\mathrm{Cu}, \mathrm{Cr}, \mathrm{Mn}, \mathrm{Zn}, \mathrm{Mo}, \mathrm{Cd}, \mathrm{Ba}, \mathrm{Sb}$, and $\mathrm{Pb}$ have also the modes within the interval of greater diameters, but their anthropogenicity is decided by their high EFs.

The crustal elements occur mainly in oxides and carbonates in the Earth's crust and soil (Seinfeld and Pandis 2006). The most common such compounds are $\mathrm{SiO}_{2}, \mathrm{Al}_{2} \mathrm{O}_{3}, \mathrm{Fe}_{2} \mathrm{O}_{3}, \mathrm{CaO}$, $\mathrm{K}_{2} \mathrm{O} \mathrm{SrCO}_{3}$, and $\mathrm{CaCO}_{3}$. Rubidium occurs mainly as an ingredient of minerals, where it is never a chief constituent. It is hard to decide in which compounds it occurs in Katowice. So, instead of $\mathrm{Rb}$ compounds only, $\mathrm{Rb}$ is included into MM. It is also assumed that one half of the analytically determined mass 
Table 2 Enrichment factors (EF) for the elements determined in the particular PM fractions (averages in the measuring period)

\begin{tabular}{|c|c|c|c|c|c|c|c|c|c|c|c|c|c|}
\hline & $\mathrm{PM}_{0.03-0.06}$ & $\mathrm{PM}_{0.06-0.108}$ & $\mathrm{PM}_{0.108-0.17}$ & $\mathrm{PM}_{0.17-0.26}$ & $\mathrm{PM}_{0.26-0.4}$ & $\mathrm{PM}_{0.4-0.65}$ & $\mathrm{PM}_{0.65-1}$ & $\mathrm{PM}_{1-1.6}$ & $\mathrm{PM}_{1.6-2.5}$ & $\mathrm{PM}_{2.5-4.4}$ & $\mathrm{PM}_{4.4-6.8}$ & $\mathrm{PM}_{6.8-10}$ & $\mathrm{PM}_{10-40}$ \\
\hline $\mathrm{Al}$ & 4 & 4 & 4 & 3 & 1 & 0 & 0 & 1 & 1 & 1 & 1 & 1 & 1 \\
\hline $\mathrm{Si}$ & 1 & 1 & 1 & 1 & 1 & 1 & 1 & 1 & 1 & 1 & 1 & 1 & 1 \\
\hline K & 6 & 12 & 15 & 32 & 41 & 32 & 16 & 5 & 2 & 2 & 2 & 1 & 2 \\
\hline $\mathrm{Ca}$ & 8 & 8 & 9 & 10 & 8 & 5 & 5 & 6 & 6 & 8 & 8 & 10 & 16 \\
\hline $\mathrm{Sc}$ & 10,343 & 11,007 & 11,384 & 10,449 & 5454 & 1610 & 2004 & 2408 & 2578 & 3401 & 3740 & 4555 & 10,590 \\
\hline $\mathrm{Ti}$ & 704 & 683 & 766 & 711 & 415 & 125 & 88 & 41 & 35 & 22 & 27 & 53 & 38 \\
\hline V & 5174 & 5073 & 5758 & 5344 & 3177 & 1030 & 708 & 329 & 281 & 175 & 214 & 416 & 299 \\
\hline $\mathrm{Cr}$ & 2861 & 2651 & 3439 & 2757 & 1902 & 661 & 450 & 196 & 147 & 102 & 122 & 229 & 233 \\
\hline Mn & 1146 & 1113 & 1242 & 1187 & 726 & 281 & 193 & 88 & 69 & 50 & 57 & 99 & 103 \\
\hline $\mathrm{Fe}$ & 6 & 10 & 13 & 23 & 26 & 21 & 19 & 17 & 12 & 12 & 11 & 10 & 10 \\
\hline Co & 3718 & 3796 & 3946 & 3891 & 2110 & 665 & 441 & 190 & 157 & 94 & 133 & 224 & 152 \\
\hline $\mathrm{Ni}$ & 248 & 254 & 365 & 335 & 368 & 207 & 102 & 53 & 28 & 27 & 27 & 35 & 185 \\
\hline $\mathrm{Cu}$ & 4525 & 5278 & 6047 & 7618 & 7667 & 5477 & 3738 & 1705 & 783 & 496 & 498 & 537 & 459 \\
\hline $\mathrm{Zn}$ & 533 & 1270 & 1761 & 5507 & 7662 & 7314 & 4980 & 2326 & 893 & 572 & 480 & 432 & 832 \\
\hline As & 22,337 & 30,662 & 22,888 & 39,686 & 42,096 & 31,297 & 20,188 & 10,473 & 3648 & 1938 & 1519 & 1837 & 1879 \\
\hline $\mathrm{Se}$ & - & - & - & - & 23,590 & 67,909 & 27,406 & 7887 & - & - & - & - & - \\
\hline $\mathrm{Br}$ & 51,992 & 59,949 & 33,908 & 59,334 & 58,738 & 39,492 & 17,060 & 3580 & 896 & 388 & 518 & 811 & 700 \\
\hline $\mathrm{Rb}$ & 42 & 71 & 46 & 71 & 89 & 81 & 34 & 8 & 2 & 2 & 2 & 2 & 3 \\
\hline $\mathrm{Sr}$ & 141 & 144 & 134 & 108 & 77 & 24 & 16 & 9 & 8 & 7 & 8 & 11 & 13 \\
\hline Mo & 11,004 & 16,848 & 16,954 & 20,010 & 9790 & 4238 & 2166 & 1052 & 791 & 665 & 552 & 618 & 1142 \\
\hline $\mathrm{Ag}$ & 868,286 & 829,102 & 955,600 & 764,006 & 533,982 & 183,388 & 106,841 & 41,655 & 43,820 & 23,261 & 33,143 & 66,811 & 47,981 \\
\hline $\mathrm{Cd}$ & 558,812 & 616,641 & 764,601 & 534,027 & 451,093 & 171,596 & 105,929 & 52,944 & 25,544 & 16,344 & 22,204 & 42,383 & 34,496 \\
\hline $\mathrm{Sb}$ & $3,652,494$ & $3,550,660$ & $3,986,969$ & $3,850,606$ & $2,302,153$ & 786,619 & 495,293 & 201,125 & 162,216 & 92,544 & 122,594 & 261,825 & 178,252 \\
\hline $\mathrm{Te}$ & - & - & - & - & - & - & - & - & - & - & - & - & - \\
\hline $\mathrm{Ba}$ & 406 & 388 & 434 & 408 & 227 & 78 & 55 & 32 & 23 & 18 & 21 & 32 & 23 \\
\hline $\mathrm{Pb}$ & 7703 & 9712 & 6782 & 12,725 & 13,475 & 9790 & 6690 & 3648 & 1257 & 677 & 517 & 610 & 630 \\
\hline
\end{tabular}

$[\mathrm{Ca}]_{\mathrm{A}}$ of $\mathrm{Ca}$ comes from $\mathrm{CaO}$ and the second half from $\mathrm{CaCO}_{3}$.

Concluding, for $\mathrm{PM}_{1-40},[\mathrm{MM}]=\left[\mathrm{SiO}_{2}\right]+\left[\mathrm{Al}_{2} \mathrm{O}_{3}\right]+$ $\left[\mathrm{Fe}_{2} \mathrm{O}_{3}\right]+[\mathrm{CaO}]+\left[\mathrm{K}_{2} \mathrm{O}\right]+\left[\mathrm{CaCO}_{3}\right]+\left[\mathrm{SrCO}_{3}\right]+[\mathrm{Rb}]$, and for $\mathrm{PM}_{0.03-1},[\mathrm{MM}]=\left[\mathrm{SiO}_{2}\right]+\left[\mathrm{Al}_{2} \mathrm{O}_{3}\right]+[\mathrm{CaO}]+\left[\mathrm{CaCO}_{3}\right]$.

The anthropogenic elements in PM come mainly from oxides, sulfides, sulfates, nitrates, chlorates, and fluorides (Chow 1995; Kyotani and Iwatsuki 2002). Sulfides, sulfates, nitrates, chlorates, and fluorides are soluble in water, and oxides are assumed not to be (Rogula-Kozłowska et al. 2013a). ATM comprises $\mathrm{SO}_{4}{ }^{2-}, \mathrm{NO}_{3}{ }^{-}$, and $\mathrm{NH}_{4}{ }^{+}$(i.e., secondary ions, SI; $\left.[\mathrm{SI}]=\left[\mathrm{NH}_{4}{ }^{+}\right]+\left[\mathrm{NO}_{3}{ }^{-}\right]+\left[\mathrm{SO}_{4}{ }^{2-}\right]\right)$, all the anthropogenic elements, and, except for $\mathrm{Cl}^{-}, \mathrm{Na}^{+}, \mathrm{Se}, \mathrm{Br}, \mathrm{Sr}, \mathrm{Sc}, \mathrm{Co}, \mathrm{Ag}, \mathrm{Rb}$, Mo, and Te, their oxides. The mass [ATM] of ATM is the sum of the masses of all the substances from these three ATM subcategories.

The part of [SI] in [ATM] is the mass of those ions that were not bound in compounds in SIM; i.e., the mass contribution of SI to [ATM] is equal to [SI]-[SIM].

For three fractions, $\mathrm{PM}_{0.26-0.4}, \mathrm{PM}_{0.4-0.65}$, and $\mathrm{PM}_{0.65-1}$, [SI]-[SIM] is negative. It is due to the overestimation of the masses of PM-bound $\mathrm{NH}_{4}\left(\mathrm{SO}_{4}\right)_{2}$ and $\mathrm{HN}_{4} \mathrm{NO}_{3}$ in the Eqs. 2,
$3,4,5$, and 6 , where these compounds are assumed to occur in each PM fraction and that ambient $\mathrm{SO}_{4}{ }^{2-}$ is entirely, and prior to $\mathrm{NO}_{3}{ }^{-}$, neutralized by $\mathrm{NH}_{4}{ }^{+}$. However, only when the molar ratio $\mathrm{NH}_{4}{ }^{+} / \mathrm{SO}_{4}{ }^{2-}$ is not less than 2 , the ambient $\mathrm{H}_{2} \mathrm{SO}_{4}$ can be totally neutralized (Seinfeld and Pandis 2006), and $\mathrm{PM}_{2.5}$ can be acidic even when this ratio is greater than $2\left(\mathrm{SO}_{4}{ }^{2-} / \mathrm{NH}_{4}{ }^{+}\right.$ $\leq 0.5$; Pathak et al. 2009; Huang et al. 2011). Therefore, some part of ambient $\mathrm{SO}_{4}{ }^{2-}$ might not have reacted with $\mathrm{NH}_{3}$ and occurred as $\mathrm{H}_{2} \mathrm{SO}_{4}$. The proportions of the concentrations of total anions to total cations (equivalent ion balance, $\Sigma_{\text {anions }}$ ' $\Sigma_{\text {cations, }}$, Table 1), relatively high for these three fractions (still less than 1, but higher than for other fractions), confirm the possibility of the $\mathrm{H}_{2} \mathrm{SO}_{4}$ presence in $\mathrm{PM}$. Another cause of [SI]-[SIM] being negative may be the loss of semi-volatile $\mathrm{HN}_{4} \mathrm{NO}_{3}$ from samples during sampling (almost a wholeweek exposure of a filter in summer), but such artifacts are significant only in PM samples very rich in ammonium (Pathak et al. 2009).

Because the absolute values of the negative [SI]-[SIM] do not exceed $1.5 \%$ of the $\mathrm{PM}$ mass for any of $\mathrm{PM}_{0.26-0.4}, \mathrm{PM}_{0.4}$ 0.65 , and $\mathrm{PM}_{0.65-1}, 0$ was substituted for the negative [SI]-[SIM] in the formulas for calculation of [ATM]. 
The mass of the oxides of an element in PM is assumed to be the mass of its most common in PM oxide and is stoichiometrically computed from the mass of this element.

In general, more than $70 \%$ of the mass of each of $\mathrm{K}, \mathrm{Ti}, \mathrm{Zn}$, $\mathrm{Ba}$, and $\mathrm{Pb}$ from a PM sample passes into water (RogulaKozłowska et al. 2013a), i.e., is water-soluble. In this paper, only $25 \%$ of their analytically determined in PM masses are assumed to come from insoluble oxides, and such a percentage of their mass is taken to compute the $\mathrm{K}_{2} \mathrm{O}, \mathrm{TiO}_{2}, \mathrm{ZnO}$, $\mathrm{BaO}$, and $\mathrm{PbO}$ masses in ATM. The solubility of each of $\mathrm{Cr}$, $\mathrm{Mn}$, and $\mathrm{Sb}$ is between 30 and $50 \%$, and $50 \%$ of each of their analytical mass in $\mathrm{PM}$ is used to calculate the $\mathrm{Cr}_{2} \mathrm{O}_{3}, \mathrm{MnO}$, and $\mathrm{Sb}_{2} \mathrm{O}_{3}$ masses in ATM. The solubility of $\mathrm{Fe}$ and $\mathrm{Cu}$ is less than $30 \%$; the masses of the insoluble PM-bound $\mathrm{Fe}_{2} \mathrm{O}_{3}$ and $\mathrm{CuO}$ in ATM are computed from $75 \%$ of the analytically determined masses of $\mathrm{Fe}$ and $\mathrm{Cu}$, respectively. Similarly, the solubility of each of $\mathrm{V}, \mathrm{Ni}, \mathrm{As}$, and $\mathrm{Cd}$, which had not been considered earlier in (Rogula-Kozłowska et al. 2013a), is assumed to be $25 \%$, and $75 \%$ of the analytically determined masses of these elements are taken to compute the masses of $\mathrm{V}_{2} \mathrm{O}_{5}, \mathrm{NiO}, \mathrm{As}_{2} \mathrm{O}_{5}$, and $\mathrm{CdO}$ in ATM. Consequently, $75 \%$ of the analytically determined masses of $\mathrm{K}, \mathrm{Ti}, \mathrm{Zn}, \mathrm{Ba}$, and $\mathrm{Pb}$; $50 \%$ of the masses of $\mathrm{Cr}, \mathrm{Mn}$, and $\mathrm{Sb}$; and $25 \%$ of the masses of $\mathrm{Fe}, \mathrm{Cu}, \mathrm{V}, \mathrm{Ni}, \mathrm{As}$, and $\mathrm{Cd}$ are included in [ATM]. They contribute to [ATM] as the masses of these parts of the elements that are in compounds with PM-bound sulfides, sulfates, nitrates, chlorates, etc.

The analytically determined masses of PM-bound $\mathrm{Cl}^{-}$, $\mathrm{Na}^{+}, \mathrm{Se}, \mathrm{Br}, \mathrm{Sr}, \mathrm{Sc}, \mathrm{Co}, \mathrm{Ag}, \mathrm{Rb}, \mathrm{Mo}$, and Te are included into [ATM] in total - the mass of $\mathrm{Cl}^{-}$because $\mathrm{Cl}^{-}$does not occur in oxides, the mass of $\mathrm{Na}^{+}$because $100 \%$ of $\mathrm{Na}$ is soluble (Rogula-Kozłowska et al. 2013a), and the masses of the rest arbitrarily, because either they do not occur in oxides or their compounds occurring in PM are hard to determine.

Concluding, in $\mathrm{PM}_{1-40},[\mathrm{ATM}]=\left[\mathrm{TiO}_{2}\right]+[\mathrm{ZnO}]+[\mathrm{BaO}]+$ $[\mathrm{PbO}]+\left[\mathrm{Cr}_{2} \mathrm{O}_{3}\right]+[\mathrm{MnO}]+\left[\mathrm{Sb}_{2} \mathrm{O}_{3}\right]+[\mathrm{CuO}]+\left[\mathrm{V}_{2} \mathrm{O}_{5}\right]+[\mathrm{NiO}]+$ $\left[\mathrm{As}_{2} \mathrm{O}_{5}\right]+[\mathrm{CdO}]+0.75([\mathrm{Ti}]+[\mathrm{Zn}]+[\mathrm{Ba}]+[\mathrm{Pb}])+0.5([\mathrm{Cr}]+$ $[\mathrm{Mn}]+[\mathrm{Sb}])+0.25([\mathrm{Cu}]+[\mathrm{V}]+[\mathrm{Ni}]+[\mathrm{As}]+[\mathrm{Cd}])+\left[\mathrm{Cl}^{-}\right]+$ $\left[\mathrm{Na}^{+}\right]+[\mathrm{Se}]+[\mathrm{Br}]+[\mathrm{Sc}]+[\mathrm{Co}]+[\mathrm{Ag}]+[\mathrm{Mo}]+[\mathrm{Te}]+$ ([SI]-[SIM])

And in $\mathrm{PM}_{0.03-1},[\mathrm{ATM}]=\left[\mathrm{K}_{2} \mathrm{O}\right]+\left[\mathrm{TiO}_{2}\right]+[\mathrm{ZnO}]+$ $[\mathrm{BaO}]+[\mathrm{PbO}]+\left[\mathrm{Cr}_{2} \mathrm{O}_{3}\right]+[\mathrm{MnO}]+\left[\mathrm{Sb}_{2} \mathrm{O}_{3}\right]+\left[\mathrm{Fe}_{2} \mathrm{O}_{3}\right]+$ $[\mathrm{CuO}]+\left[\mathrm{V}_{2} \mathrm{O}_{5}\right]+[\mathrm{NiO}]+\left[\mathrm{As}_{2} \mathrm{O}_{5}\right]+[\mathrm{CdO}]+0.75([\mathrm{~K}]+[\mathrm{Ti}]+$ $[\mathrm{Zn}]+[\mathrm{Ba}]+[\mathrm{Pb}])+0.5([\mathrm{Cr}]+[\mathrm{Mn}]+[\mathrm{Sb}])+0.25([\mathrm{Fe}]+[\mathrm{Cu}]+$ $[\mathrm{V}]+[\mathrm{Ni}]+[\mathrm{As}]+[\mathrm{Cd}])+\left[\mathrm{Cl}^{-}\right]+\left[\mathrm{Na}^{+}\right]+[\mathrm{Se}]+[\mathrm{Br}]+[\mathrm{Sr}]+$ $[\mathrm{Sc}]+[\mathrm{Co}]+[\mathrm{Ag}]+[\mathrm{Rb}]+[\mathrm{Mo}]+[\mathrm{Te}]+([\mathrm{SI}]-[\mathrm{SIM}])$.

For each PM basic fraction, the mass [UM] of the unidentified matter UM is as follows: $[\mathrm{UM}]=[\mathrm{PM}]-([\mathrm{SOM}]+$ $[\mathrm{POM}]+[\mathrm{EC}]+[\mathrm{SIM}]+[\mathrm{MM}]+[\mathrm{ATM}])$.

The calculations of the masses of the compounds in MM, ATM, and in other categories, too, are somewhat speculative. The assumptions, taken from the cited papers, are simplifications and are neither always nor everywhere true. Moreover, because of alternate use of quartz and membrane substrates, the chemical constituents whose masses were used in the computations were sampled at different times. Thus, Fig. 3 presents only a very rough estimate of the chemical composition of the 13 basic PM fraction in Katowice.

The UM mass share in $\mathrm{PM}_{10-40}, 37.5 \%$, is the greatest among all the UM shares in the basic fractions (Fig. 3). Most probably, UM consists of water, organic compounds, and nitrates that evaporate during handling of the PM samples and of unidentified compounds (Chow 1995; Tsyro 2005; Seinfeld and Pandis 2006). The inaccuracies in identification of compounds in OM, MM, SIM, and ATM also affect UM. The MM mass content of $\mathrm{PM}_{10-40}$ is higher than that of other basic fractions; the ATM content of it is also high, so $\mathrm{PM}_{10-40}$ is supposed to be hygroscopic (containing hygroscopic $\mathrm{Al}_{2} \mathrm{O}_{3}$, $\mathrm{CaCl}_{2}, \mathrm{NaCl}$, etc.) and to contain some unidentified PMbound water. Also, UM shares in $\mathrm{PM}_{0.17-0.26}$ and $\mathrm{PM}_{1.6-2.5}$ are significant. The former fraction contains a great share of SIM whose mass could be underestimated in the stoichiometric computations; the latter contains much water, like $\mathrm{PM}_{10-40}$, and probably also underestimated amount of OM.

ATM contributes to $\mathrm{PM}_{0.03-0.26}$ mass much, about $29 \%$ in average (mode in $0.17-0.26 \mu \mathrm{m}$, Fig. 4), to $\mathrm{PM}_{0.03-0.06}$ even $44 \%$. Besides, POM contributes to $\mathrm{PM}_{0.03-0.26}$ mass $28 \%$, EC $-3.1 \%$, and MM-3.2\%, so primary matter makes $64 \%$ of $\mathrm{PM}_{0.03-0.26}$. Secondary matter (SOM and SIM) is about $16.6 \%$ in the $\mathrm{PM}_{0.03-0.26}$ mass.

The composition of $\mathrm{PM}_{0.26-1.6}$ is entirely different from that of $\mathrm{PM}_{0.03-0.26}$. SOM and SIM prevail in $\mathrm{PM}_{0.26-1.6}$. The mass size distributions of SOM, SIM, EC, and POM have modes in $0.4-0.65 \mu \mathrm{m}$ (Fig. 4). The average secondary matter mass content (SOM and SIM) in $\mathrm{PM}_{0.26-1.6}$ is $56.6 \%$, and POM, EC, MM, and ATM together are $29.2 \%$.

The EC mass content of $\mathrm{PM}_{1.6-40}$ is about $5.3 \%$ and is much greater than those of $\mathrm{PM}_{0.03-0.26}$ and $\mathrm{PM}_{0.26-1.6}$; $\mathrm{MM}$

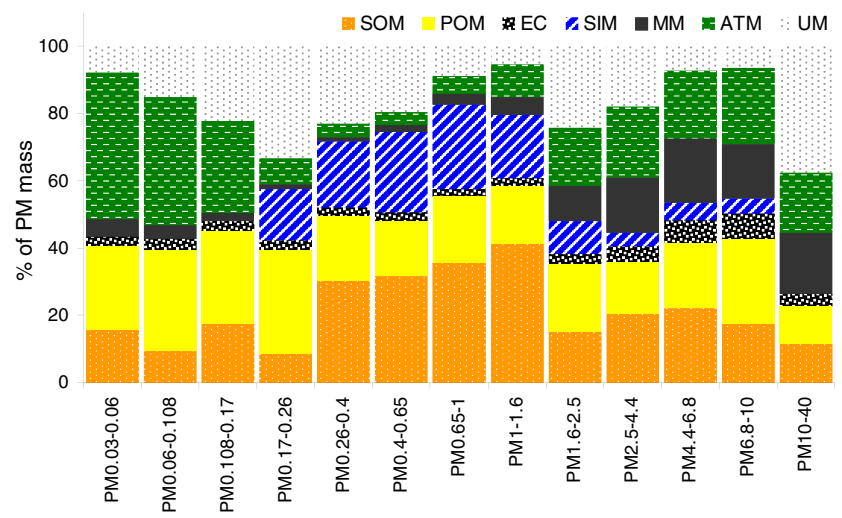

Fig. 3 Averaged in the measuring period mass contributions to PM of secondary organic matter (SOM), primary organic matter (POM), elemental carbon (EC), secondary inorganic matter (SIM), mineral matter (MM), anthropogenic trace matter (ATM), and unidentified matter (UM) 


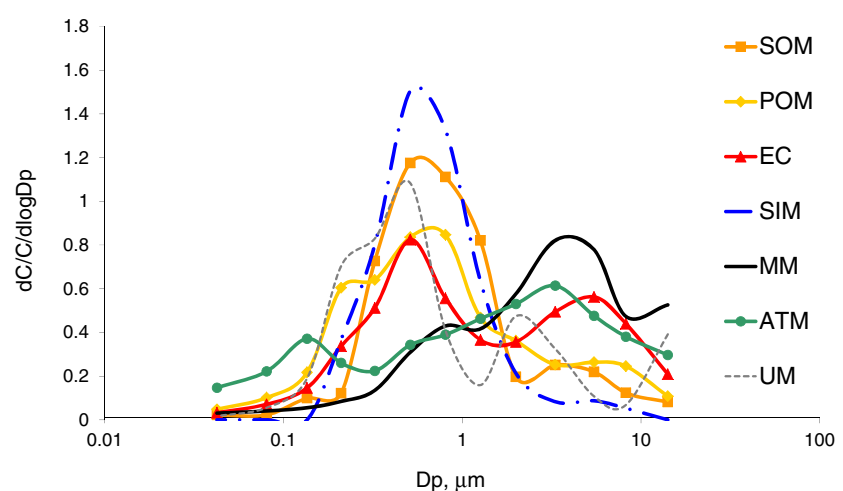

Fig. 4 Mass size distributions of secondary organic matter (SOM), primary organic matter (POM), elemental carbon (EC), secondary inorganic matter (SIM), mineral matter (MM), anthropogenic trace matter (ATM), and unidentified matter (UM)

and ATM are 16.1 and $19.7 \%$ in $\mathrm{PM}_{1.6-40}$. So, in $\mathrm{PM}_{1.6-40}$, primary matter is $59.3 \%$ and secondary matter (SOM and SIM) is no more than $22 \%$. All the group mass size distributions have modes within the interval of great particle diameters.

It has appeared that the PM at the Katowice sampling point consists of three quite sharply differing fractions: $\mathrm{PM}_{0.03-0.26}$, $\mathrm{PM}_{0.26-1.6}$, and $\mathrm{PM}_{1.6-40}$.

$\mathrm{PM}_{0.03-0.26}$ is composed of primary metal oxides and salts, primary organic compounds, and, in lesser amounts, of EC and secondary compounds. This PM fraction comes most probably from road traffic and industry (combustion of fossil fuels an biomass in heating and power plants, iron and steel industry, metallurgy) (Geller et al. 2006; Maricq 2007; Sanderson et al. 2014; Kumar et al. 2013), and by mass, it is about $13 \%$ of the total PM.

$\mathrm{PM}_{0.26-1.6}$, mainly secondary, contributes to total PM about $59 \%$. It contains SOM and SIM from transformations of precursory gaseous compounds (from road traffic, solid fuel combustion, industry, etc.). Its ambient concentrations depend strongly on and are very sensitive to the variations of atmospheric conditions (insolation, precipitation, air pressure and temperature, EC concentration, etc.) and ambient concentrations of oxidants (such as ozone) (Seinfeld and Pandis 2006; Pathak et al. 2009; Huang et al. 2011). Even the tendency of their variations is hard to forecast because the factors upon which they depend are interrelated. Nevertheless, in Southern Poland, the secondary matter formation seems to be equally effective relative to the PM concentrations in heating and non-heating periods: in both these periods of 2009 in Zabrze, a city about $15 \mathrm{~km}$ east of Katowice, secondary matter was about $50 \%$ of $\mathrm{PM}_{1}$ (Rogula-Kozłowska and Klejnowski 2013), and the present study proves it to be $48 \%$ in Katowice in the non-heating period of 2012.

$\mathrm{PM}_{1.6-40}$, about $28 \%$ of the PM mass, contains mainly primary coarse particles of mineral/soil and road dust (various salts, hygroscopic aluminosilicates), soot (EC), particles from construction sites, etc. The $\mathrm{PM}_{1.6-40}$ concentrations are probably directly proportional to the rates of these particle resuspensions; therefore, they depend on wind, erosion, and corrosion. These big particles can contain volatile and semivolatile compounds from SOM and SIM on their surfaces. Most probably, the majority of the $\mathrm{PM}_{1.6-40}$-bound compounds from SOM and SIM are adsorbed on big particles of soot (EC) agglomerated during transport or released by inefficient household ovens.

\section{PAHs in size-segregated PM}

PM-bound PAHs are in POM; some, in favorable conditions, are precursory to SOM (Zhang and Ying 2012). In Katowice, the 16 determined PAHs ( $\mathrm{PAH})$ were no more than $0.1 \%$ of the POM mass in each $\mathrm{PM}_{0.17-0.4}$ basic sub-fraction and slightly more than $0.1 \%$ in each basic sub-fraction of $\mathrm{PM}_{6.8-40}$ (Fig. 5). In the sub-fractions of $\mathrm{PM}_{0.4-6.8}$, they were $0.2-0.47 \%$ and in $\mathrm{PM}_{0.03-0.06}-0.42 \%$. Among all the 13 basic fraction-bound $\Sigma \mathrm{PAHs}$, the ambient concentrations of the $\mathrm{PM}_{0.4-1.6^{-}}$and $\mathrm{PM}_{2.5-4.4}$-bound $\Sigma \mathrm{PAH}$ were the highest and those of the $\mathrm{PM}_{0.03-0.26^{-}}, \mathrm{PM}_{1.6-2.5^{-}}$, and $\mathrm{PM}_{4.4-40^{-}}$ bound - the lowest (Fig. 5). So, both the ambient concentrations and the shares in POM of $\Sigma \mathrm{PAH}$ from three out of all four basic sub-fractions of the $\mathrm{PM}_{0.26-1.6}$ (except $\mathrm{PM}_{0.26-0.4}$ ) were relatively high.

The ambient concentrations of $\Sigma \mathrm{PAH}$ from the basic subfractions of $\mathrm{PM}_{0.03-0.26}$ and $\mathrm{PM}_{1.6-40}$ were low, but the $\Sigma \mathrm{PAH}$ contents of POM and of PM were high in some of them. In the interval $0.03-0.26 \mu \mathrm{m}, \Sigma \mathrm{PAH}$ contents of POM and of PM in basic fractions decrease and the $\Sigma \mathrm{PAH}$ ambient concentration grows with growing particle diameter. In $0.26-1.6 \mu \mathrm{m}$, the concentrations of $\Sigma \mathrm{PAH}$ and $\Sigma \mathrm{PAH}$ content of both POM and PM grow with growing particle diameter; in 1.6-40 $\mu \mathrm{m}$, they rather decrease. Despite possible artifacts from sampling (related to semi-volatile PAHs), the behavior of PM-bound $\Sigma \mathrm{PAH}$ partitions again $\mathrm{PM}$ into $\mathrm{PM}_{0.03-0.26}, \mathrm{PM}_{0.26-1.6}$, and $\mathrm{PM}_{1.6-40}$ at the site in Katowice.

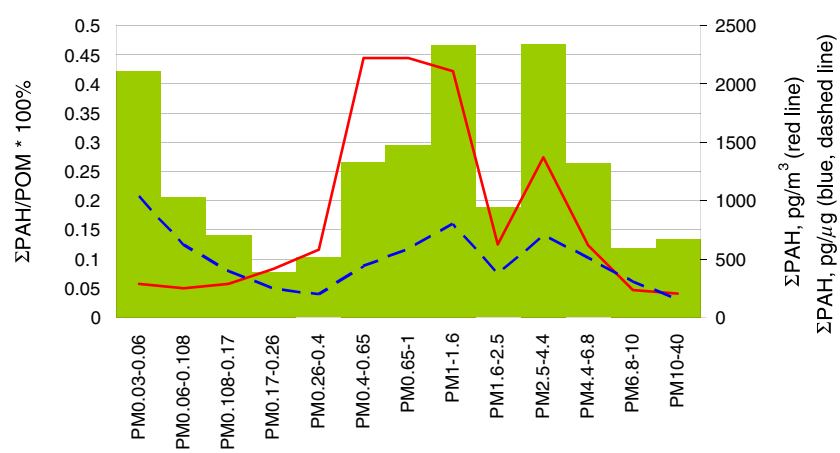

Fig. 5 Ambient concentrations of $16 \mathrm{PAH}\left(\mathrm{SPAH}, \mathrm{pg} / \mathrm{m}^{3}\right.$; red line $)$ and

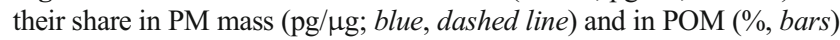


Like POM, $\Sigma \mathrm{PAH}$ has a bimodal mass size distribution; the main mode is in the interval $0.65-1 \mu \mathrm{m}$ of the diameters of the particles contained in $\mathrm{PM}_{0.26-1.6}$ and rich in $\mathrm{EC}$; the second one is in the interval 1.6-40 $\mu \mathrm{m}$ of the diameters of big particles rich in EC and MM (Fig. 4).

Despite relatively low mass contribution of PAHs to POM, and very low to PM, PM-bound PAHs can be characteristic of a PM source and can be used to trace the origin of PM (Ravindra et al. 2008; Tobiszewski and Namieśnik 2012). They may be used as markers or molecular diagnostic ratios which can be computed based on the PAH concentrations. The markers of a source are the PAHs that are characteristic of this source. The molecular diagnostic ratios are the mutual proportions of the ambient concentrations of a single PAH or groups of PAHs that have similar physicochemical properties (Tobiszewski and Namieśnik 2012). Although the diagnostic ratios are more convenient in use than markers, they should be used cautiously because they are sensitive to atmospheric conditions and can be the same for different PAH sources (Dvorská et al. 2011).

In Table 3, some molecular diagnostic ratios (MDR) for the PAHs present in majority of the PM fractions in Katowice are presented. MDR computed for some PAHs in $\mathrm{PM}_{0.03-0.26}, \mathrm{PM}_{0.26-1.6}$, and $\mathrm{PM}_{1.6-40}$ indicate biomass and fossil fuel combustion as the PAH sources (Tobiszewski and Namieśnik 2012). The $\mathrm{An} /(\mathrm{An}+\mathrm{Ph})$ and $\mathrm{Ph} /(\mathrm{Ph}+\mathrm{An})$ suggest that a greater part of $\mathrm{PM}_{0.03-}$ 0.26 and the PAHs in it came from road traffic and that $\mathrm{PM}_{0.26-1.6}$ came from combustion of solid fuels. The Fl/ $(\mathrm{Fl}+\mathrm{Py})$ indicates combustion of liquid fossil fuels as the source of the $\mathrm{PM}_{0.26-1.6}$-bound PAHs and combustion of coal, grass, and wood as the source of $\mathrm{PM}_{0.03}$

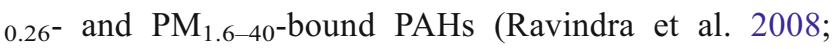
Tobiszewski and Namieśnik 2012).

Each sample taking lasted several days, and the occurrence of artifacts, as well negative (evaporation of semi-volatile PAHs) as positive (adsorbing some gaseous PAHs on particles of EC, salts, mineral particles, etc.), during sampling cannot be excluded (Ravindra et al. 2008; Dvorská et al. 2011;

Table 3 PAH molecular diagnostic ratios (MDR) for $\mathrm{PM}_{0.03-0.26}$, $\mathrm{PM}_{0.26-1.6}$, and $\mathrm{PM}_{1.6-40}$

\begin{tabular}{llll}
\hline $\mathrm{MDR}$ & $\mathrm{PM}_{0.03-0.26}$ & $\mathrm{PM}_{0.26-1.6}$ & $\mathrm{PM}_{1.6-40}$ \\
\hline $\mathrm{An} /(\mathrm{An}+\mathrm{Ph})$ & 0.67 & 0.30 & - \\
$\mathrm{Ph} /(\mathrm{Ph}+\mathrm{An})$ & 0.33 & 0.70 & - \\
$\mathrm{Fl} /(\mathrm{Fl}+\mathrm{Py})$ & 0.68 & 0.44 & 0.67 \\
$\mathrm{BaA} /(\mathrm{BaA}+\mathrm{Ch})$ & 0.61 & 0.51 & 0.90 \\
$\mathrm{BaA} / \mathrm{BaP}$ & 1.54 & 1.29 & 1.08 \\
$\mathrm{IP} /(\mathrm{IP}+\mathrm{BghiP})$ & - & 0.33 & - \\
$\mathrm{BaP} /$ BghiP & - & 4.70 & - \\
\hline
\end{tabular}

Tobiszewski and Namieśnik 2012). Although the application of the cascade impactor prevented the drawn atmospheric aerosol from blowing through the filters, limiting the effects of these artifacts, and although for each PM basic fraction, the samples from the whole sampling period were combined into one sample to be analyzed for PAHs, still, the method used was not sensitive enough to determine the most stable PAHs, IP, and BghiP, in some very fine and coarse fractions of PM (Table 1), what makes the reasoning using MDR uncertain.

$\mathrm{BaP}$, a well-studied five-ring hydrocarbon, is of special importance to environmental toxicology. It is one of the most mutagenic and carcinogenic hydrocarbons known (Nikolao et al. 1984; Ravindra et al. 2008). Its importance consists also in its being a basis for defining the toxic equivalence factor (TEF) and the carcinogenic equivalent (CEQ) for other PAHs. Namely, TEF for a PAH is defined relative to the TEF of BaP, the latter being assumed to be 1; CEQ of a group of PAHs is the linear combination of the TEFs and the ambient concentrations of these PAHs. TEF expresses the absolute toxicity of a particular PAH, CEQ - the toxicity of a group of ambient PAHs (Nisbet and LaGoy 1992). The mutagenic equivalent (MEQ) or the TCDD toxic equivalent (TEQ), defined in Rogula-Kozłowska et al. (2013b), can also be useful in assessing the influence of a PAH mixture on human health.

The ambient concentrations of $\Sigma \mathrm{PAH}$ and $\mathrm{BaP}$ from $\mathrm{PM}_{0.03-0.26}, \mathrm{PM}_{0.26-1.6}$, and $\mathrm{PM}_{1.6-40}$ and CEQ, MEQ, and TEQ for these fractions at the site in Katowice are presented in Fig. 6. Although $\mathrm{PM}_{0.26-1.6^{-}}$and $\mathrm{PM}_{1.6-40^{-}}$ bound $\mathrm{BaP}$ concentrations are almost equal (concentration of $\mathrm{PM}_{1.6-40}$-bound $\mathrm{BaP}$ is a little higher than that of $\mathrm{PM}_{0.26-1.6}$-bound $\mathrm{BaP}$ ), the $\mathrm{PM}_{0.26-1.6}$-bound $\Sigma \mathrm{PAHs}$ pose much greater risk to human health than the $\Sigma$ PAHs from $\mathrm{PM}_{1.6-40}$. Although the mass share of $\Sigma \mathrm{PAH}$ in $\mathrm{PM}_{0.03-0.26}$ is greater than in $\mathrm{PM}_{1.6-40}$ (Fig. 5), the ambient concentrations of $\mathrm{PM}_{1.6-40}$-bound $\mathrm{BaP}$ and $\Sigma \mathrm{PAH}$ are very high, higher than those of $\mathrm{PM}_{0.03-0.26}$-bound $\mathrm{BaP}$ and $\mathrm{SPAH}$. In Katowice, the health risk from coarse $\mathrm{PM}$ can be greater than the risk from very fine PM (Fig. 6).

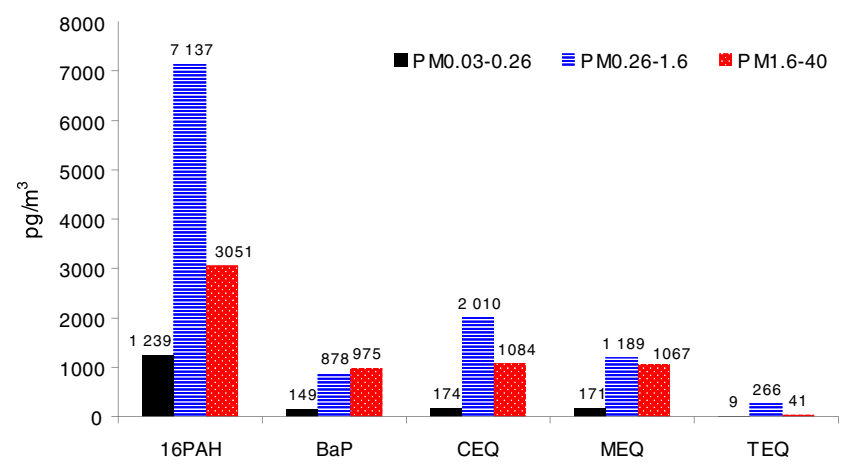

Fig. 6 Concentrations of $\triangle \mathrm{PAH}$ and $\mathrm{BaP}$ and values of $\mathrm{CEQ}, \mathrm{MEQ}$, and TEQ for $\mathrm{PM}_{0.03-0.26}, \mathrm{PM}_{0.26-1.6}$, and $\mathrm{PM}_{1.6-40}$ 


\section{Conclusions}

In Katowice, the partition of the particle (aerodynamic) diameters into three intervals, $0.03-0.26,0.26-1.6$, and $1.6-40 \mu \mathrm{m}$, by the stochastic behavior of the properties of ambient particles is very clear, and the fractions $\mathrm{PM}_{0.03-0.26}, \mathrm{PM}_{0.26-1.6}$, and $\mathrm{PM}_{1.6-40}$ obviously differ. Despite some technical limitations of the whole experiment, such as using in the computations the concentrations of PM components that were sampled at different times, duration of particular sample takings (several days), and arbitral simplifications in the chemical mass closure scheme, the revealed differences in the physicochemical properties of these three fractions are so systematic that the partition cannot be accidental but rather related with the origin of $\mathrm{PM}$ at the site (structure of emissions).

The average ambient concentration of $\mathrm{PM}_{0.26-1.6}$ was $14.5 \mu \mathrm{g} / \mathrm{m}^{3}$. By mass, $\mathrm{PM}_{0.26-1.6}$ was about $59 \%$ of the total $\mathrm{PM}, \mathrm{PM}_{1.6-40}$ was $28 \%$, and $\mathrm{PM}_{0.03-0.26}$ was $13 \%$. $\mathrm{PM}_{0.03-0.26}$ and $\mathrm{PM}_{1.6-40}$ consisted mainly of primary matter (64 and $59 \%$ of their masses), and $\mathrm{PM}_{0.26-}$ 1.6 consisted of secondary matter (57\% of its mass). Thus, arising of the greater part of PM in Southern Poland depends on the conditions upon which the physicochemical transformations of primary matter in the air depend. Lowering of PM concentrations should therefore consist in imposing limits on emissions of precursory gases from combustion. Combustion is the primary source of PAHs, and, as it is shown in this paper, from among $\mathrm{PM}_{0.03-0.26}, \mathrm{PM}_{0.26-1.6}$, and $\mathrm{PM}_{1.6-40}$, the greatest health hazard from the PAH content in Katowice is posed by $\mathrm{PM}_{0.26-1.6}$.

The finest particles, mainly primary, coming usually from nucleation, condensation, or sublimation of organic (PAHs) or inorganic (oxides and salts) gases from combustion of coal, biomass, and liquid fuels, in Katowice are in $\mathrm{PM}_{0.03-0.26}$. Limits on the emissions from combustion, besides affecting the secondary part of $\mathrm{PM}_{0.26-}$ 1.6, will lower amounts of primary PM. It will perhaps not decrease essentially the PM (mass) concentrations, but it will significantly lower the health hazard from PM.

The coarsest particles, $\mathrm{PM}_{1.6-40}$, are mainly not only primary particles from erosion of road surface, constructions, cars, soil, etc., but also big agglomerates of soot and big particles of salts from combustion of solid fuels in household ovens or in the open air (burning plant material in allotment gardens, grass fires, etc.). They contain significant amounts of PAHs, and the health hazard from these $\mathrm{PM}_{16-40}$-bound PAHs can be higher than the health hazard from the PAHs contained in $\mathrm{PM}_{0.03-0.26}$.
Funding The work was carried out within the project no. N523 564038 (ID 72074) and no. 2012/07/D/ST10/02895 (ID 202319) financed by the National Science Centre, Poland (NCN).

Conflict of interest The author declares that she has no conflict of interest.

Open Access This article is distributed under the terms of the Creative Commons Attribution 4.0 International License (http://creativecommons.org/licenses/by/4.0/), which permits unrestricted use, distribution, and reproduction in any medium, provided you give appropriate credit to the original author(s) and the source, provide a link to the Creative Commons license, and indicate if changes were made.

\section{References}

Adachi K, Tainosho Y (2004) Characterization of heavy metal particles embedded in tire dust. Environ Int 30:1009-1017

Alves CA, Gomes J, Nunes T, Duarte M, Calvo A, Custódio D, Pio C, Karanasiou A, Querol X (2015) Size-segregated particulate matter and gaseous emissions from motor vehicles in a road tunnel. Atmos Res 153:134-144

Amato F, Alastue A, de la Rosa J, Gonzalez Castanedo Y, Sánchez de la Campa AM, Pandolfi M, Lozano A, Contreras González J, Querol X (2014) Trends of road dust emissions contributions on ambient air particulate levels at rural, urban and industrial sites in southern Spain. Atmos Chem Phys 14:3533-3544

Atkinson RW, Mills IC, Walton HA, Anderson HR (2015) Fine particle components and health - a systematic review and meta-analysis of epidemiological time series studies of daily mortality and hospital admissions. J Expo Sci Environ Epidemiol 25:208-214

Belis CA, Karagulian F, Larsen BR, Hopke PK (2013) Critical review and meta-analysis of ambient particulate matter source apportionment using receptor models in Europe. Atmos Environ 69:94-108

Calvo A, Alves C, Castro A, Pont V, Vicente AM, Fraile R (2013) Research on aerosol sources and chemical composition: past, current and emerging issues. Atmos Res 120-121:1-28

Castro LM, Pio CA, Harrison RM, Smith DJT (1999) Carbonaceous aerosol in urban and rural European atmospheres: estimation of secondary organic carbon concentrations. Atmos Environ 33: $2771-2781$

Cheng MT, Lin YC, Chio CP, Wang CF, Kuo CY (2005) Characteristics of aerosols collected in central Taiwan during an Asian dust event in spring 2000. Chemosphere 61:1439-1450

Chow JC (1995) Measurement methods to determine compliance with ambient air quality standards for suspended particles. J Air Waste Manag Assoc 45:320-382

Daher N, Saliba N, Shihadeh AL, Jaafar M, Baalbaki R, Shafer MM, Schauer JJ, Sioutas C (2014) Oxidative potential and chemical speciation of size-resolved particulate matter (PM) at near-freeway and urban background sites in the greater Beirut area. Sci Total Environ 470-471:417-426

Dvorská A, Lammel G, Klánová J (2011) Use of diagnostic ratios for studying source apportionment and reactivity of ambient polycyclic aromatic hydrocarbons over Central Europe. Atmos Environ 45(2): $420-427$

EC (2008) Directive 2008/50/EC of the European Parliament and of the Council of 21 May 2008 on ambient air quality and cleaner air for Europe

Englert N (2004) Fine particles and human health-a review of epidemiological studies. Toxicol Lett 149:235 
Friedlander SK (1970) The characterization of aerosols distributed with respect to size and chemical composition-I. Aerosol Sci Technol 1: 295-307

Friedlander SK (1971) The characterization of aerosols distributed with respect to size and chemical composition-II. Aerosol Sci Technol 2:331-340

Geller MD, Ntziachristos L, Mamakos A, Samaras Z, Schmitz DA, Froines JR, Sioutas C (2006) Physicochemical and redox characteristics of particulate matter (PM) emitted from gasoline and diesel passenger cars. Atmos Environ 40:6988-7004

Huang RJ, Zhang Y, Bozzetti C, Ho KF, Cao JJ, Han Y, Daellenbach KR, Slowik JG, Platt SM, Canonaco F, Zotter P, WolfR PSM, Bruns EA, Crippa M, Ciarelli G, Piazzalunga A, Schwikowski M, Abbaszade G, Schnelle-Kreis J, Zimmermann R, An Z, Szidat S, Baltensperger U, El Haddad I, Prévôt ASH (2014) High secondary aerosol contribution to particulate pollution during haze events in China. Nature 514:218-222

Huang X, Qiu R, Chak K, Chan PRK (2011) Evidence of high PM2.5 strong acidity in ammonia-rich atmosphere of Guangzhou, China: transition in pathways of ambient ammonia to form aerosol ammonium at $\left[\mathrm{NH}_{4}{ }^{+}\right] /\left[\mathrm{SO}_{4}{ }^{2-}\right]=1.5$. Atmos Res 99:488-495

Karlsson H, Gustafsson J, Cronholm P, Möller L (2009) Size-dependent toxicity of metal oxide particles - a comparison between nano- and micrometer size. Toxicol Lett 188:112-118

Klejnowski K, Pastuszka JS, Rogula-Kozłowska W, Talik E, Krasa A (2012) Mass size distribution and chemical composition of the surface layer of summer and winter airborne particles in Zabrze, Poland. Bull Environ Contam Toxicol 88:255-259

Kong S, Wen B, Chen K, Yin Y, Li L, Li Q, Yuan L, Li X, Sun X (2014) Ion chemistry for atmospheric size-segregated aerosol and depositions at an offshore site of Yangtze River Delta region China. Atmos Res 147-148:205-226

Kumar P, Pirjola L, Ketzel M, Harrison RM (2013) Nanoparticle emissions from 11 non-vehicle exhaust sources - a review. Atmos Environ 67:252-277

Kyotani T, Iwatsuki M (2002) Characterization of soluble and insoluble components in PM2.5 and PM10 fractions of airborne particulate matter in Kofu city, Japan. Atmos Environ 36(4):639-649

Li Z, Liang Y, Zhou J, Sun X (2014) Impacts of de-icing salt pollution on urban road greenspace: a case study of Beijing. Front Environ Sci Eng 8:747-756

Maricq MM (2007) Chemical characterization of particulate emission from diesel engines: a review. Aerosol Sci 38:1079-1118

Massolo L, Muller A, Tueros M, Rehwagen M, Franck U, Ronco A, Herbath O (2002) Assessment of mutagenicity and toxicity of different-size fractions of air particulates from La Plata, Argentina, and Lepzig, Germany. Environ Toxicol 17:219-231

Nikolao K, Masclet PM, Mouvier G (1984) Sources and chemical reactivity of polynuclear aromatic hydrocarbons in the atmosphere- a critical review. Sci Total Environ 32:102-132

Nisbet ICT, LaGoy PK (1992) Toxic equivalency factors (TEFs) for polycyclic aromatic hydrocarbons (PAHs). Regul Toxicol Pharmacol 16:290-300

Paasonen P, Asmi A, Petäjä T, Kajos MK, Äijälä M, Junninen H, Holst T, Abbatt JPD, Arneth A, Birmili W, van der Gon HD, Hamed A, Hoffer A, Laakso L, Laaksonen A, Leaitch WR, Plass-Dülmer C, Pryor SC, Räisänen P, Swietlicki E, Wiedensohler A, Douglas WR, Kulmala V-MKaM (2013) Warming-induced increase in aerosol number concentration likely to moderate climate change. Nat Geosci 6:438-442

Pant P, Harrison RM (2013) Estimation of the contribution of road traffic emissions to particulate matter concentrations from field measurements: a review. Atmos Environ 77:78-97

Pastuszka JS, Rogula-Kozłowska W, Zajusz-Zubek E (2010) Characterization of $\mathrm{PM}_{10}$ and $\mathrm{PM}_{2.5}$ and associated heavy metals at the crossroads and urban background site in Zabrze, Upper
Silesia, Poland, during the smog episodes. Environ Monit Assess 168:613-627

Pathak RK, Wu WS, Wang T (2009) Summertime PM2.5 ionic species in four major cities of China: nitrate formation in an ammonia-deficient atmosphere. Atmos Chem Phys 9:1711-1722

Pokorná P, Hovorka J, Klána M, Hopke PK (2015) Source apportionment of size resolved particulate matter at a European air pollution hot spot. Sci Total Environ 502:172-183

Pope CA, Dockery DW (2006) Health effects of fine particulate air pollution: lines that connect. J Air Waste Manag Assoc 56:709-742

Putaud JP, Van Dingenen R, Alastuey A, Bauer H, Birmili W, Cyrys J, Flentje H, Fuzzi S, Gehrig R, Hansson HC, Harrison RM, Herrmann H, Hitzenberger R, Hüglin C, Jones AM, Kasper-Giebl A, Kiss G, Kousa A, Kuhlbush TAJ, Löschau G, Maenhaut W, Molnar A, Moreno T, Pekkanen J, Perrino C, Pitz M, Puxbaum H, Querol X, Rodriguez S, Salma I, Schwarz J, Smolik J, Schneider J, Spindler G, ten Brink H, Tursic J, Viana M, Wiedensohler A, Raes F (2010) A European aerosol phenomenology - 3: physical and chemical characteristics of particulate matter from 60 rural, urban, and kerbside sites across Europe. Atmos Environ 44:1308-1320

Ravindra K, Sokhi R, Van Grieken R (2008) Atmospheric polycyclic aromatic hydrocarbons: source attribution, emission factors and regulation. Atmos Environ 42(13):2895-2921

Rogula-Kozłowska W, Błaszczak B, Szopa S, Klejnowski K, Sówka I, Zwoździak A, Jabłońska M, Mathews B (2013a) PM2.5 in the central part of Upper Silesia, Poland: concentrations, elemental composition, and mobility of components. Environ Monit Assess 185(1): 581-601

Rogula-Kozłowska W, Klejnowski K (2013) Submicrometer aerosol in rural and urban backgrounds in southern Poland: primary and secondary components of $\mathrm{PM}_{1}$. Bull Environ Contam Toxicol 90:103109

Rogula-Kozłowska W, Klejnowski K, Rogula-Kopiec P, Ośródka L, Krajny E, Błaszczak B, Mathews B (2014) Spatial and seasonal variability of the mass concentration and chemical composition of $\mathrm{PM}_{2.5}$ in Poland. Air Qual Atmos Health 7:41-58

Rogula-Kozłowska W, Kozielska B, Klejnowski K (2013b) Concentration, origin and health hazard from fine particle-bound PAH at three characteristic sites in Southern Poland. Bull Environ Contam Toxicol 91:349-355

Sanderson P, Delgado Saborit JM, Harrison RM (2014) A review of chemical and physical characterisation of atmospheric metallic nanoparticles'. Atmos Environ 94:353-365

Seinfeld JH, Pandis SN (2006) Atmospheric chemistry and physics: from air pollution to climate change. Wiley

Spindler G, Brüggemann E, Gnauk T et al (2010) A four-year size-segregated characterization study of particles $\mathrm{PM}_{10}, \mathrm{PM}_{2.5}$ and $\mathrm{PM}_{1}$ depending on air mass origin at Melpitz. Atoms Environ 44:164173

Tobiszewski M, Namieśnik J (2012) PAH diagnostic ratios for the identification of pollution emission sources. Environ Pollute 162:110 119

Tsyro SG (2005) To what extent can aerosol water explain the discrepancy between model calculated and gravimetric PM10 and PM2.5. Atmos Chem Phys 5:515-532

Turpin BJ, Lim HJ (2001) Species contributions to PM2.5 mass concentrations: revisiting common assumptions for estimating organic mass. Aerosol Sci Technol 35:602-610

Viana M, Kuhlbusch TAJ, Querol X, Alastuey A, Harrison RM, Hopke PK, Winiwarter W, Vallius M, Szidat S, Prevot ASH, Hueglin C, Bloemen H, Wahlin P, Zecchi R, Kasper-Giebl A, Maenhaut W, Hitzenberger R (2008) Source apportionment of particulate matter in Europe: a review of methods and results. J Aerosol Sci 39:827849 
Wahlin P, Berkowicz R, Palmgren F (2006) Characterisation of trafficgenerated particulate matter in Copenhagen. Atmos Environ 40: 2151-2159

Zhang H, Ying Q (2012) Secondary organic aerosol from polycyclic aromatic hydrocarbons in Southeast Texas. Atmos Environ 55: 279-287
Zhang W, Tong Y, Wang H, Chen L, Ou L, Wang X, Liu G, Zhu Y (2014) Emission of metals from pelletized and uncompressed biomass fuels combustion in rural household stoves in China. Sci Rep 8(4):5611 